\begin{tabular}{|l|l}
\hline $\begin{array}{l}\text { 2. TO: (Receiving Organization) } \\
\text { Distribution }\end{array}$ & $\begin{array}{l}\text { 3. From: (Originating Organization) } \\
\text { SYStems }\end{array}$ \\
\hline H. Proj./Prog./Dept./Div.: & $\begin{array}{l}\text { 6. Design Authority/Design AgentCog. Engr.: } \\
\text { DAWN E. ADAMS }\end{array}$ \\
\hline
\end{tabular}

8. Originator Remarks:

FOR RELEASE

11. Receiver Remarks:
4. Related EDT No:

N/A

7. Purchase Order No.:

$\mathrm{N} / \mathrm{A}$

9. Equip./Component No.:

$\mathrm{N} / \mathrm{A}$

10. System/BIdg./Facility:

$\mathrm{N} / \mathrm{A}$

12. Major Assm. Dwg. No.:

$\mathrm{N} / \mathrm{A}$

13. Permit'Permit Application No.:

$\mathrm{N} / \mathrm{A}$

14. Required Response Date:

$\mathrm{N} / \mathrm{A}$

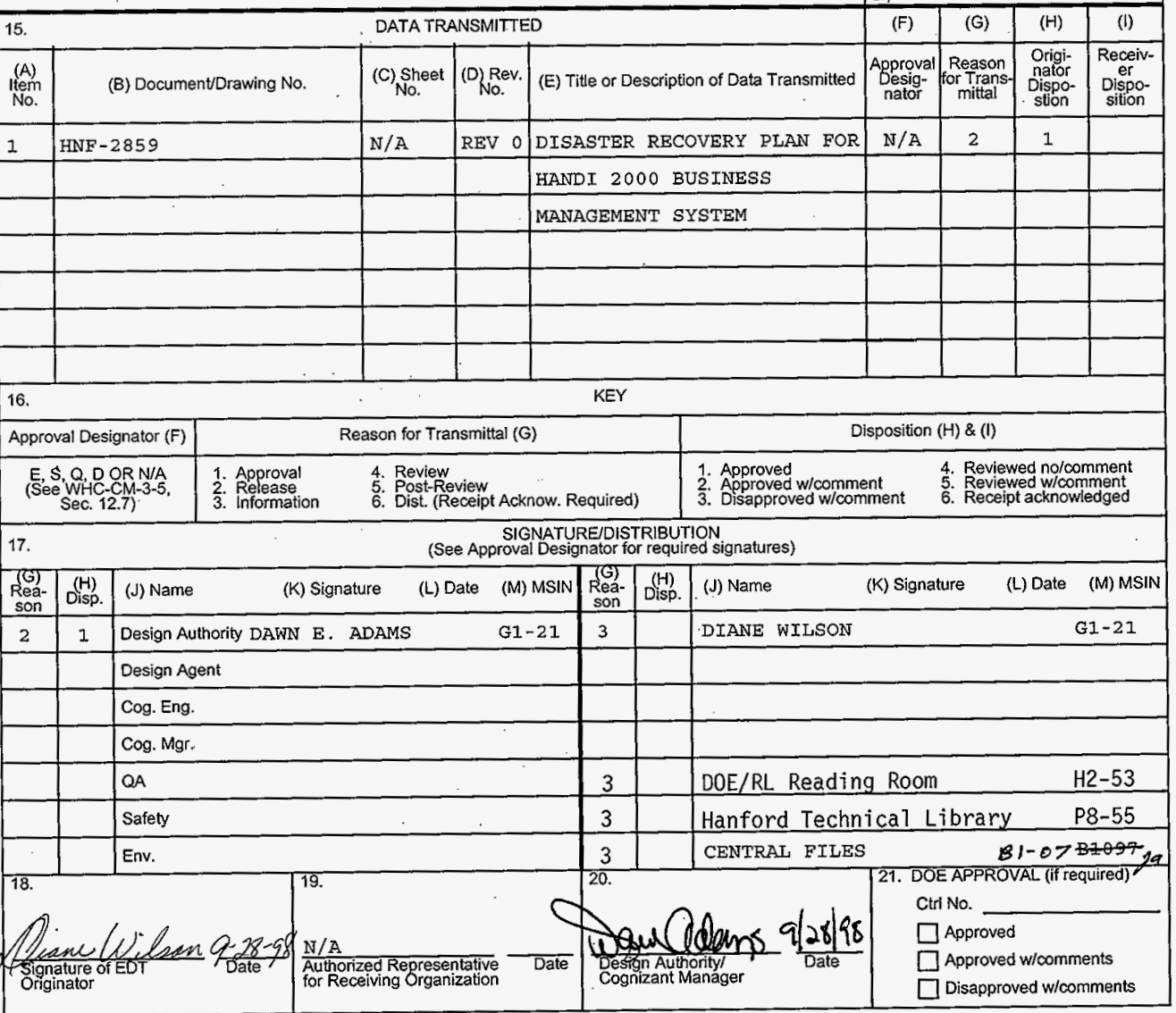




\title{
DISASTER RECOVERY PLAN FOR HANDI 2000 BUSINESS MANAGEMENT SYSTEM
}

\author{
Dawn E. Adams, FDH \\ 2355 Stevens, MSIN G1-21 \\ Richland, WA 99352 \\ U.S. Department of Energy Contract DE-AC06-96RL13200

$\begin{array}{lll}\text { EDT/ECN: } & 625364 & \text { UC: } 900 \\ \text { Org Code: } & \text { SL610000 } & \text { Charge Code: HANF6800 } \\ \text { B\&R Code: } & \text { EW7001000 } & \text { Total Pages: } 38\end{array}$

Key Words: HANDI 2000, BUSTNESS MANAGEMENT, DISASTER RECOVERY PLAN, H2K, BMS, PEOPLESOFT, PASSPORT

Abstract: The HANDI 2000 Disaster Recovery Plan (DRP) will provide direction for the recovery of the HANDI 2000, hardware, software and data in the even of a disaster that damages all or part of the computer equipment. This plan will make use of existing disaster recovery plans currently in place at Hanford where applicable and contains a complete list of hardware and software needed to run the HANDI 2000 systems. ...

TRADEMARK DISCLAIMER. Reference herein to any specific commercial product, process, or service by trade name, trademark, manufacturer, or otherwise, does not necessarily constitute or imply its endorsement, recommendation, or favoring by the United States Government or any agency thereof or its contractors or subcontractors.

Printed in the United States of America. To obtain copies of this document, contact: Document Control Services, P.O. Box 950, Mailstop H6-08, Richland WA 99352, Phone (509) 372-2420; Fax (509) 376-4989.

PassPort is a trademark of Indus Corporation. Peoplesoft is a trademark of PeopleSoft Corpordition. Unix is a trademark of X/Open Co. Ltd. Oracle is a trademark of Oracle Corporation P3 Primavera is a trademark of Primavera Systen S, Imos:

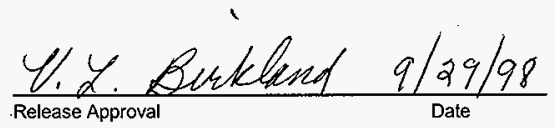

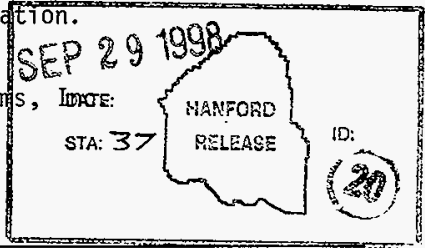

Release Stamp 


\title{
DISASTER RECOVERY PLAN
}

\author{
FOR
}

HANDI 2000

BUSINESS MANAGEMENT SYSTEM

Prepared by: Thomas J. Kuyper, LMSI Software Engineer

Prepared for: Fluor Daniel Hanford

Approved by:
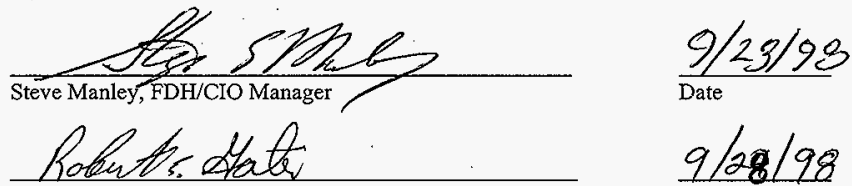

Robert E. Gates, H2K Project Director
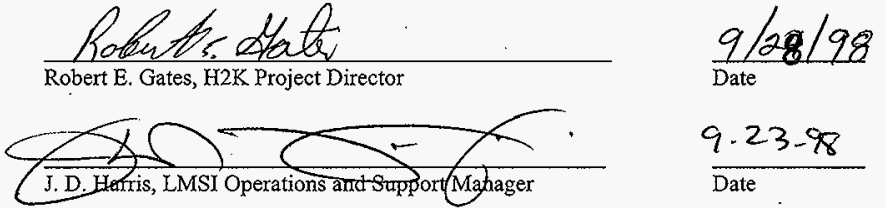

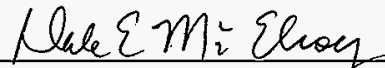

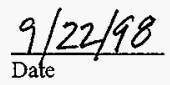

Dale E. McElroy, LMSI Telecommunifations and

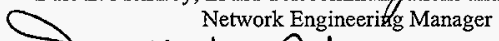
Network Engineeritg Manager

\section{wauk ylles Adans}

Dawn E. Adams, BMS Project Manager
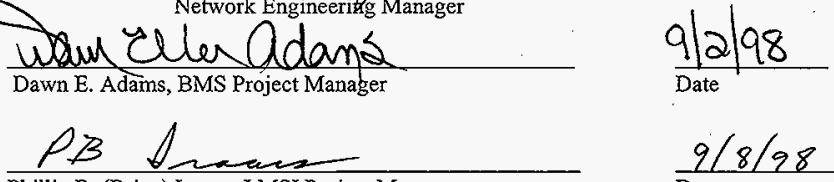

Phillip B. (Brian) Isaacs, LMSI Project Manager
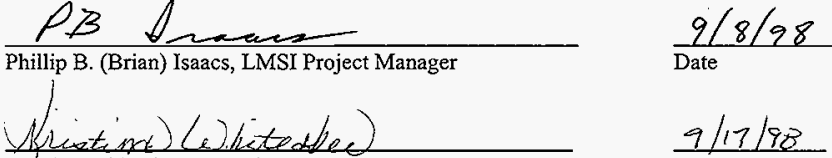

Kristina Whiteaker, INDUS Project Manager

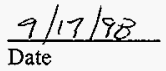




\section{TABLE OF CONTENTS}

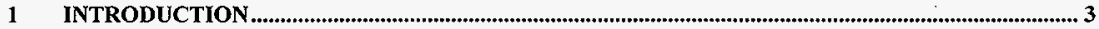

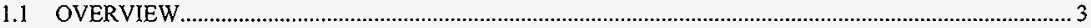

1.2 PURPOSE

1.3 SCOPE

1.4 ACRONYM DEFINITIONS

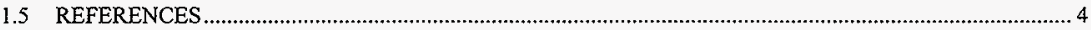

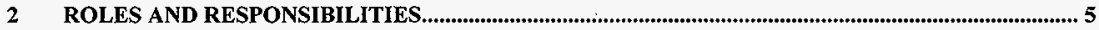

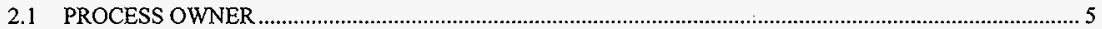

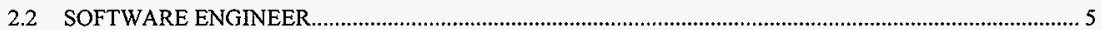

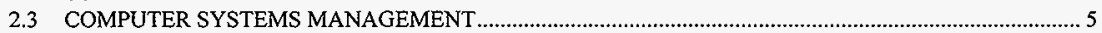

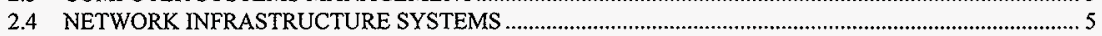

2.5 DISASTER RECOVERY MANAGER

2.6 DATA CENTER OPERATIONS MANAGER AND STAFF …............................................................

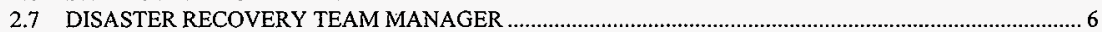

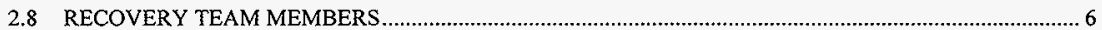

3 DISASTER RECOVERY REQUIREMENTS.......................................................................................... 7

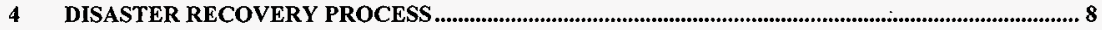

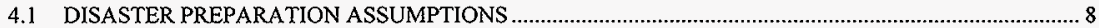

4.2 DISASTER TRAINING - EDUCATION

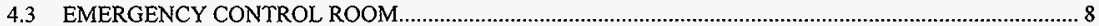

4.4 RECOVERY FLOW

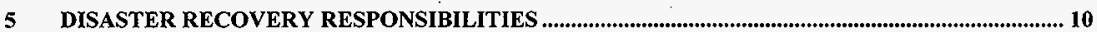

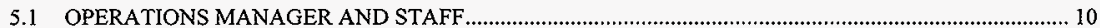

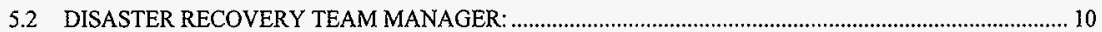

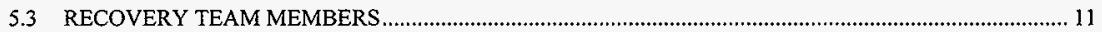

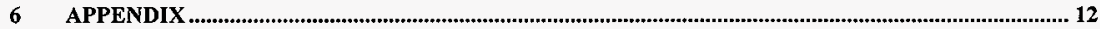

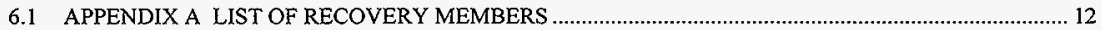

6.2 APPENDIX B INITIAL DISASTER RECOVERY TEAM MEETING ................................................... 13

6.3 APPENDIX C INITIAL DAMAGE ASSESSMENT FOR COMPUTER FACILITY …...............................14

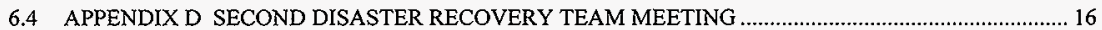

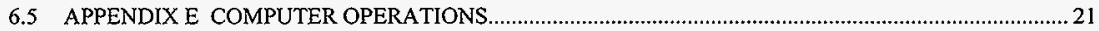

6.6 APPENDIX F PRODUCTION CONTROL

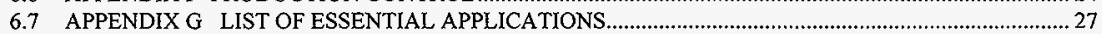

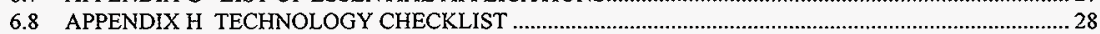

6.9 APPENDIX I MINIMUM CONFIGURATION FOR PROCESSING BMS APPLICATIONS ......................2 29

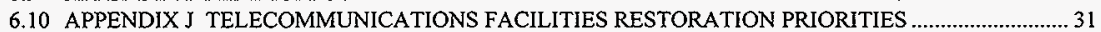

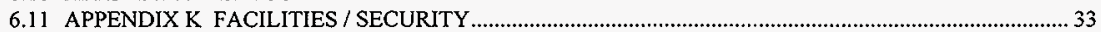

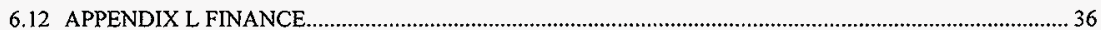

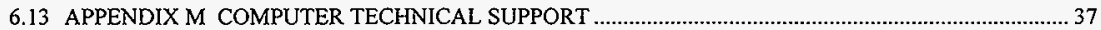




\section{INTRODUCTION}

The Hanford Data Integration 2000 (HANDI 2000) Project will result in an integrated and comprehensive set of functional applications containing core information necessary to support the Project Hanford Management Contract. It is based on the Commercial-Off-The-Shelf (COTS) product solution with commercially proven business processes. The PassPort (PP) software is an integrated application for Accounts Payable, Contract Management, Inventory Management, and Purchasing. The PeopleSoft (PS) software is an integrated application for General Ledger, Project Costing, Human Resources, Payroll, Benefits, and Training. The implementation of this set of products, as the first deliverable of the HANDI 2000 Project, is referred to as Business Management System (BMS) and Chemical Management.

\subsection{OVERVIEW}

The BMS production implementation will be complete by October 01, 1998 and the server environment will be comprised of two types of platforms. The PassPort Supply and the PeopleSoft Financials will reside on UNIX servers and the PeopleSoft Human Resources and Payroll will reside on Microsoft NT servers. Because of the wide scope and the requirements of the COTS products to run in various environments backup and recovery responsibilities are divided between two groups in Technical Operations. The Central Computer Systems Management group provides support for the UNIX/NT Backup Data Center, and the Network Infrastructure Systems group provides support for the NT Application Server Backup outside the Data Center.

The disaster recovery process is dependent on a good backup and recovery process. Information and integrated system data for determining the disaster recovery process is identified from the Fluor Daniel Hanford (FDH) Risk Assessment Plan, Contingency Plan, and Backup and Recovery Plan, and Backup Form for HANDI 2000 BMS.

Reference the following procedures:

HNF-PRO-311, Functional Security Requirements/Application Development HNF-PRO-592, Unclassified Computer Security Management Control Process HNF-PRO-596, Certifying Sensitive or Essential Computer Applications HNF-PRO-597, Preparing Contingency Plans and Disaster Recovery Plans HNF-2858, HANDI 2000 Backup and Recovery Plan

\subsection{PURPOSE}

The HANDI 2000 Disaster Recovery Plan (DRP) will provide direction for the recovery of the HANDI 2000, hardware, software and data in the event of a disaster that damages all or part of the computer equipment. This plan will make use of existing disaster recovery plans currently in place at Hanford where applicable and contains a complete list of hardware and software needed to run the HANDI 2000 systems. This DRP will provide guidelines on how to reduce risk of personal injury, limit damage to facilities, hardware, software, program applications, and data. The plan provides recovery procedures and an inventory of resources to be used for the rapid restoration of onsite computer services following a disaster. This document is not meant to replace existing procedures but to augment them.

When notice is available of an impending event that is likely to significantly disrupt controlled computer facility operations, advance actions will be taken to reduce risk of personal injury, limit damage, and enhance an orderly shutdown. The appropriate steps depend on the nature of the anticipated event but generally include the steps listed in section 5.0 DISASTER RECOVERY RESPONSIBILITIES. 


\subsection{SCOPE}

The DRP covers all hardware, operating systems, and software needed to operate the HANDI 2000 systems in all locations at the Hanford Site. This plan does not cover disaster recovery for systems that feed the BMS system. Individual departments responsible for those systems are also responsible for their disaster recovery.

\subsection{ACRONYM DEFINITIONS}

\begin{tabular}{|l|l|}
\hline \multicolumn{1}{|c|}{ Acronym } & \multicolumn{1}{c|}{ Definition } \\
\hline BMS & Business Management System \\
\hline COTS & Commercial off the Shelf \\
\hline DRP & Disaster Recovery Plan \\
\hline FDH & Fluor Daniel Hanford \\
\hline HANDI 2000 & Hanford Data Integration (Year 2000 compliant) \\
\hline HLAN & Hanford Local Area Network \\
\hline LMSI & Lockheed Martin Services, Incorporated \\
\hline MS & Microsoft \\
\hline NT & New Technology \\
\hline PP & PassPort \\
\hline PS & PeopleSoft \\
\hline WAN & Wide Area Network \\
\hline
\end{tabular}

\subsection{REFERENCES}

HNF.PRO-311

HNF-PRO-592

HNF-PRO-596

HNF-PRO-597

HNF-2858

Technical Operations

Technical Operations

Appendix A

Appendix B

Appendix $C$

Appendix D

Appendix E

Appendix $F$

Appendix $\mathrm{G}$

Appendix $\mathrm{H}$

Appendix I

Appendix $\mathrm{J}$

Appendix K

Appendix L

Appendix M
Functional Security Requirements/Application Development Unclassified Computer Security Management Control Process

Certifying Sensitive or Essential Computer Applications

Preparing Contingency Plans and Disaster Recovery Plans

HANDI 2000 Backup and Recovery Plan

Computer Systems Management Disaster Recovery Plan

Network Infrastructure Systems Area Server Report

List of Recovery Members

First Recovery Meeting

Initial Damage Assessment for Computer Facility

Second Recovery Meeting

Computer Operations

Production Control

List of Essential Applications

Technology Checklist

Minimum Configuration for Processing BMS Applications

Telecommunications Facilities Restoration Priorities

Facility Security

LMSI Finance

Computer Technical Support 


\section{ROLES AND RESPONSIBILITIES}

\subsection{PROCESS OWNER}

- Notify'Software Engineer of required system changes

- Notify Software Engineer of changes in đisaster recovery requirements

- Contact Software Engineer in the event of a disaster

- Determine the needs of the applications and plan appropriate contingency actions to be implemented

- Prepare contingency plan and operational procedures to operate during system unavailability. Alternate methods of processing (e.g., manual or local processors) should be considered if managed computer facility processing is not available. Offsite processing may not be the most expedient or desirable method of processing in the event of a disaster.

- Implement the contingency plan during the recovery process

- Identify, authorize and fund any action required by support for the respective applications, including preplanning, advance testing, etc.

- Implement application readiness with support from the Technical Operations (Computer Systems Management and Network Infrastructure Systems) as funded

\subsection{SOFTWARE ENGINEER}

- Determine department responsible for disaster recovery functions

- Forward recovery requests to appropriate department

- Annually review this plan for adequacy, hardware availability, and time to delivery for replacement hardware

- Modification of this plan

\subsection{COMPUTER SYSTEMS MANAGEMENT}

- Provide disaster recovery services for all systems in the Data Center

- Maintain a list of departmental disaster recovery personnel

- Maintain a list of assigned BMS responsible personnel with backup personnel and home, work, and pager numbers

- Annually test disaster recovery functions for the Data Center

\subsection{NETWORK INFRASTRUCTURE SYSTEMS}

- Provide disaster recovery services for all application servers outside the Data Center

- Maintain a list of departmental disaster recovery personnel

- Maintain a list of assigned BMS responsible personnel with backup personnel and home, work, and pager numbers

- Annually test disaster recovery functions for application servers

\subsection{DISASTER RECOVERY MANAGER}

- Ensures that advanced plans and required preparations for the emergency control room are accomplished and maintained on a current basis

\subsection{DATA CENTER OPERATIONS MANAGER AND STAFF}

- Reference Section 5.1 


\subsection{DISASTER RECOVERY TEAM MANAGER}

Reference Section 5.2

\subsection{RECOVERY TEAM MEMBERS}

- Reference Section 5.3 


\section{DISASTER RECOVERY REQUIREMENTS}

The requirements for disaster recovery are as follows:

- Restore a system, application, or file to any hardware platform provided platform meets minimum hardware and operating system requirements for that system, application, or file.

- Obtain replacement hardware in the event of a disaster that destroys existing hardware.

Reference to the following Appendices for Checklists to support requirement actions:

Appendix $A$ Appendix $B$ Appendix $C$ Appendix D Appendix $E$ Appendix $F$ Appendix $G$ Appendix $H$ Appendix I Appendix $J$ Appendix $K$ Appendix $L$ Appendix $M$
List of Disaster Recovery Members

First Disaster Recovery Meeting

Initial Damage Assessment for Computer Facility

Second Disaster Recovery Meeting

Computer Operations

Production Control

List of Essential Applications

Technology Checklist

Minimum Configuration for Processing BMS Applications

Telecommunications Facilities Restoration Priorities

Facility Security

LMSI Finance

Computer Technical Support 


\section{DISASTER RECOVERY PROCESS}

This procedure describes the disaster recovery process for the BMS system. It is dependent on the knowledge and expertise of disaster recovery personnel in the Technical Operation departments at Hanford. If the Technical Operation departments have an approved disaster recovery procedure in place, the existing procedure will work in conjunction with this procedure.

\subsection{DISASTER PREPARATION ASSUMPTIONS}

- Disasters may result from but not be limited to: civil disturbance, earthquake, espionage, sabotage, explosion, fire, flood, riot, resource failure, snow storm, utility failure, vandalism, hurricane or high wind.

- Defining the scope of the disaster is a prerequisite for developing effective emergency plans. It may not be necessary to implement all of the checklists of the Disaster Recovery Plan.

- Total or partial loss of a managed computer facility requires total or partial relocation of personnel and/or equipment in order to maintain normal operations and to facilitate recovery.

- Emergency, temporary restoration of telecommunication access and availability of file servers will be accomplished by redirection of communications paths and use of spare or alternate file servers. This may temporarily impact customers of a lesser service level requirement.

- Normal protective services are provided by the Hanford Site security guards. If necessary, these services are augmented by the Department of Energy (DOE) and General Services Administration (GSA) protective services. In addition, there are supplementary training and voluntary services available.

- The amount of warning time prior to the disaster impacts the amount of planning and preparations that may be done. beforehand.

- Standard evacuation plans and safety and security procedures are adhered to in the event of a disaster.

- Recovery requires the continuing productive capabilities and technical talents of all personnel.

- Risk assessments are prepared on all computers and updated every three years and when there is a change in the facility.

\subsection{DISASTER TRAINING - EDUCATION}

- The extent and quality of training undertaken by personnel largely determines the ability to survive a disaster with minimum personal injury and loss of resources. Training on building evacuation, emergency signals, fire extinguisher operation and bomb threat is given annually. Additional job specific safety and emergency training is given where appropriate. All personnel are given encouragement and assistance in acquiring emergency self-help information and training.

- Personnel training is the responsibility of line management.

- Desktop Disaster Recovery exercises are performed periodically to improve awareness of the Disaster Recovery Plan and provide a critique of the effectiveness of the plan itself.

\subsection{EMERGENCY CONTROL ROOM}

- If a controlled computer facility is seriously damaged, an emergency control room is established.

- The primary control room is room 202,2261 Stevens, Richland. Personal computers, telephones and other facilities of nearby offices will be utilized. The secondary control room is in the $339 \mathrm{~A}$ building, 300 area. The computer room and offices in the building will be utilized as needed.

- The Disaster Recovery Manager ensures that advanced plans and required preparations for the emergency control room are accomplished and maintained on a current basis. 


\subsection{RECOVERY FLOW}

The following represents a functional flow of a recovery sequence. In order to ensure completeness, it assumes a disaster of such magnitude that management of recovery would require substantial duration and delegation of recovery functions. For any specific disaster, some functions will not be applicable and often functions can be combined under a single manager. The Disaster Recovery Team designs recovery plans using the appropriate elements of this general plan.

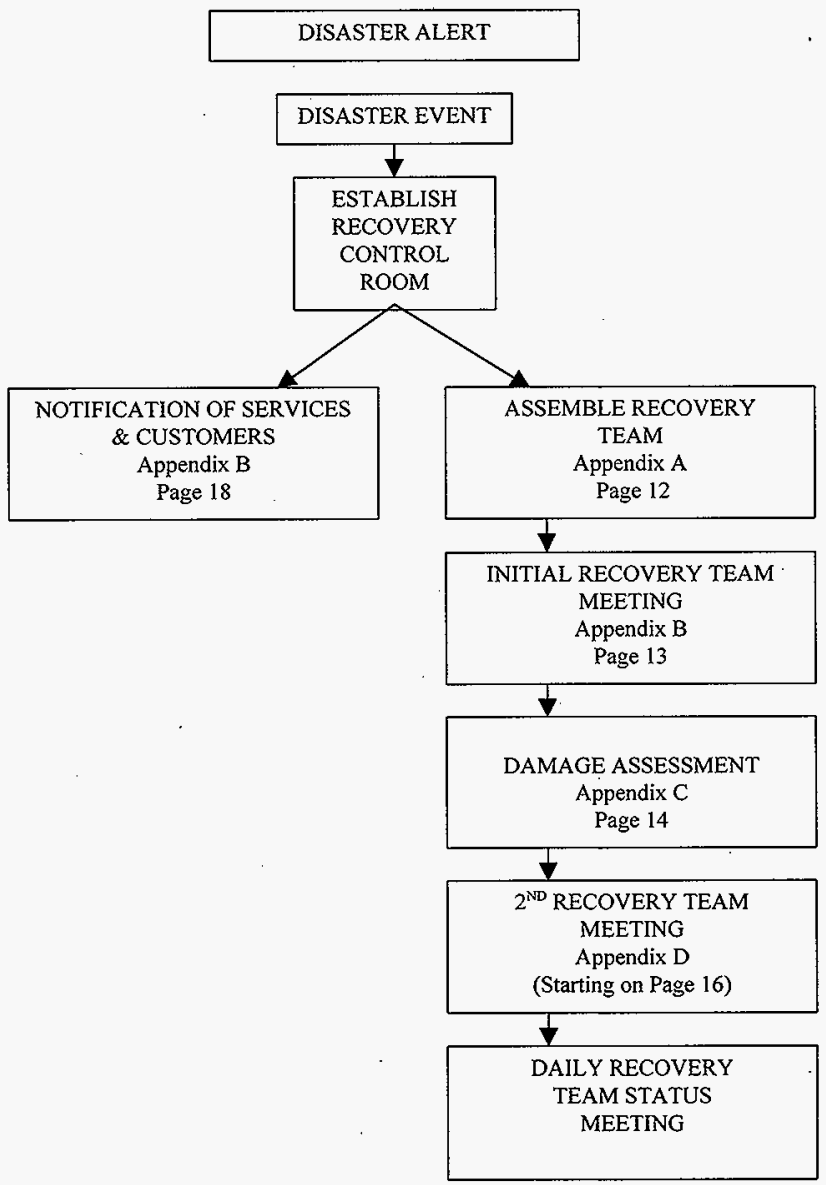




\section{DISASTER RECOVERY RESPONSIBILITIES}

\subsection{OPERATIONS MANAGER AND STAFF}

Data Center Operations Manager, or the on-duty Computer Operations Staff, is in the best position to react quickly to events that impact computer operation, and therefore, has the responsibility to initiate action as follows:

- ENSURES THAT ACTION IS TAKEN TO PROVIDE FOR THE SAFETY OF PERSONNEL.

- Ensures that action is taken to provide for appropriate Hanford Patrol coverage.

- Reports the situation, using the call lists.

- Directs interim activity to minimize damage to equipment and supplies.

- Contacts and briefs the Disaster Recovery Team Manager regarding the situation and establishes a preliminary base of operations, if required.

- If a disaster situation is declared ensures that all members of the Disaster Recovery Team are contacted and are directed to the preliminary base of operations.

When contact is made with a team member, state the following, filling in the appropriate building and facility name:

"A disaster condition has been declared in the Building Computer Facility. Report to Room 202, 2261 Stevens, as quickly as possible."

Do not wait to give further information.

- Directs recovery activity until the Disaster Recovery Team is assembled.

- Conducts the initial briefing of the Disaster Recovery Team.

\subsection{DISASTER RECOVERY TEAM MANAGER:}

The Disaster Recovery Team Manager is administratively responsible for the following:

- Ensuring the Disaster Recovery Plan is updated periodically to maintain its currency.

- Ensure that appropriate training is being given.

- Ensuring that team members are identified and that they are aware of their participation in the recovery function.

- When notice is received of an impending disaster, actions are taken to reduce risk of personal injury, limit damage, and enhance an orderly shutdown. The appropriate steps depend on the nature of the anticipated event. The following are examples of possible actions by the Disaster Recovery Team Manager:

- Acts on behalf of Lockheed Martin Services Director in the event of a declared disaster.

- Directs the recovery action and efforts of the recovery team.

- Assign damage-limiting measures.

- Decide at what point in the progression of events to proceed with shutdown and evacuation.

- Advise the Director's Staff, Appropriate Disaster Recovery Team members and appropriate Safety, Security and Public Relations personnel of the pending event.

- Occurrence Reporting and Processing of Operations Information.

- Alert assignees to prepare to implement the following assignments when directed to do so by the Disaster Recovery Team Manager:

- Ensure personnel are evacuated if appropriate.

- Ensure damage-limiting measures on all computers and computer related hardware are taken.

- Ensure computers, air conditioning, and electrical equipment is appropriately shut down.

- Ensure security is provided for evacuated areas.

- Notify assignees to implement assignments. 


\subsection{RECOVERY TEAM MEMBERS}

Disaster Recovery Team Members are selected for their knowledge of key functional areas or organizations that would be required to provide quick recovery in the event of a disaster. Their responsibilities include:

- Be familiar with the disaster recovery plan and their expected contribution to the recovery process.

- Respond if called upon in the event of a disaster notification.

- Direct the recovery process in their area of responsibility.

- Provide status updates to the manager as requested. 


\section{APPENDIX}

\subsection{APPENDIX A LIST OF RECOVERY MEMBERS}

This is a sample list of positions necessary for the post disaster recovery team. Due to the sensitive nature of home phone numbers, each department is responsible to maintain an ON CALL list of team responders and their backups for each position.

\section{COMPUTER SYSTEM MANAGEMENT DISASTER RECOVERY TEAM}

\section{COMPUTER SYSTEM MANAGEMENT}

DISASTER RECOVERY TEAM

\begin{tabular}{|l|l|l|l||}
\hline \multicolumn{1}{|c|}{ FUNCTIONAL AREA } & \multicolumn{1}{c||}{ NELEPHONE NUMBER } \\
\hline \hline MANAGER & HOME & WORK \\
\hline COMPUTER SYSTEMS MANAGEMENT & & & \\
\hline COMPUTER OPERATIONS & & & \\
\hline NT SUPPORT & & & \\
\hline UNIX SUPPORT & & & \\
\hline COMPUTER TECHNICAL SUPPORT & & & \\
ALTERNATE & & & \\
\hline INFORMATION \& SCIENTIFIC SYSTEMS & & & \\
\hline FACILITIES & & & \\
\hline BUSINESS MANAGEMENT & & & \\
\hline ALTERNATE & & & \\
\hline DATA NETWORK & & & \\
\hline PRODUCTION CONTROL & & & \\
\hline ALTERNATE & & & \\
\hline SAFETY (300, 700 AREAS) & & & \\
\hline SECURITY (BWP) & & & \\
\hline TELECOMMUNICATIONS & & & \\
\hline
\end{tabular}




\subsection{APPENDIX B INITIAL DISASTER RECOVERY TEAM MEETING}

This section contains a checklist agenda, general checklists to be utilized by Recovery Team Mernber and hardware information for the first recovery team meeting held after the notification of a disaster is received.

\section{INITIAL DISASTER RECOVERY TEAM MANAGER FIRST RECOVERY TEAM MEETING CHECKLIST}

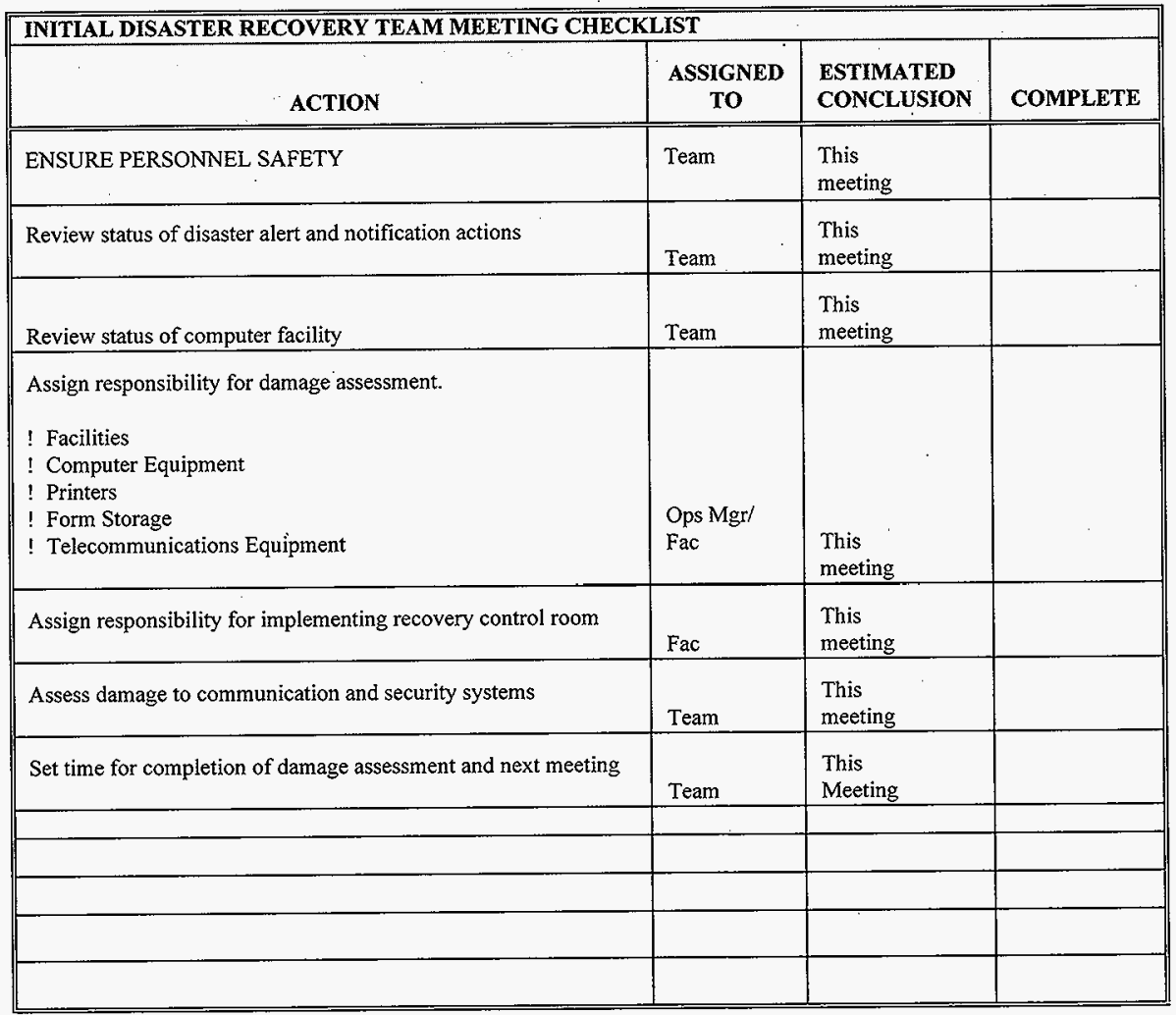

Fac-Facilities Team-Disaster Recovery Team

Ops Mgr-Operations Shift Manager 


\subsection{APPENDIX C INITIAL DAMAGE ASSESSMENT FOR COMPUTER FACILITY}

The Computer Operation's members of the Disaster Recovery Team are responsible for the following operating areas during the disaster recovery process. The damage will be assessed in detail and in coordination with other Disaster Recovery Team members as required. Each department is responsible to maintain a list of equipment in their various areas of responsibility.

\section{INITIAL DAMAGE ASSESSMENT CHECKLIST-COMPUTER ROOM}

\begin{tabular}{|c|c|c|c|c|}
\hline \multicolumn{5}{|c|}{ INITIAL DAMAGE ASSESSMENT CHECKLIST } \\
\hline COMPUTER ROOM & Location: & & & \multirow[b]{2}{*}{ COMMENTS } \\
\hline EQUIPMENT & $\begin{array}{l}\text { OPER- } \\
\text { ABLE }\end{array}$ & $\begin{array}{l}\text { PART. } \\
\text { OPER. }\end{array}$ & $\begin{array}{l}\text { NOT } \\
\text { OPER. }\end{array}$ & \\
\hline \multicolumn{5}{|l|}{ Electrical Service } \\
\hline \multicolumn{5}{|l|}{ Air Conditioners } \\
\hline \multicolumn{5}{|l|}{ Consoles and PC } \\
\hline \multicolumn{5}{|l|}{ File Servers } \\
\hline \multicolumn{5}{|l|}{ Fire Control System } \\
\hline \multicolumn{5}{|l|}{$\begin{array}{l}\text { Telecommunications } \\
\text { Equipment }\end{array}$} \\
\hline \multicolumn{5}{|l|}{ Magnetic Tape Equip. } \\
\hline \multicolumn{5}{|l|}{ Terminals } \\
\hline \multicolumn{5}{|l|}{ Copier } \\
\hline \multicolumn{5}{|l|}{ Shredder } \\
\hline \multicolumn{5}{|l|}{$\begin{array}{l}\text { Other Equipment in } \\
\text { Area from Equipment } \\
\text { list }\end{array}$} \\
\hline & & & & \\
\hline & & & & \\
\hline & & & & \\
\hline & & & & \\
\hline & & & & \\
\hline & & & & \\
\hline & & & & \\
\hline & & & & \\
\hline
\end{tabular}




\section{INITIAL DAMAGE ASSESSMENT CHECKLIST-MISCELLANEOUS EQUIPMENT}

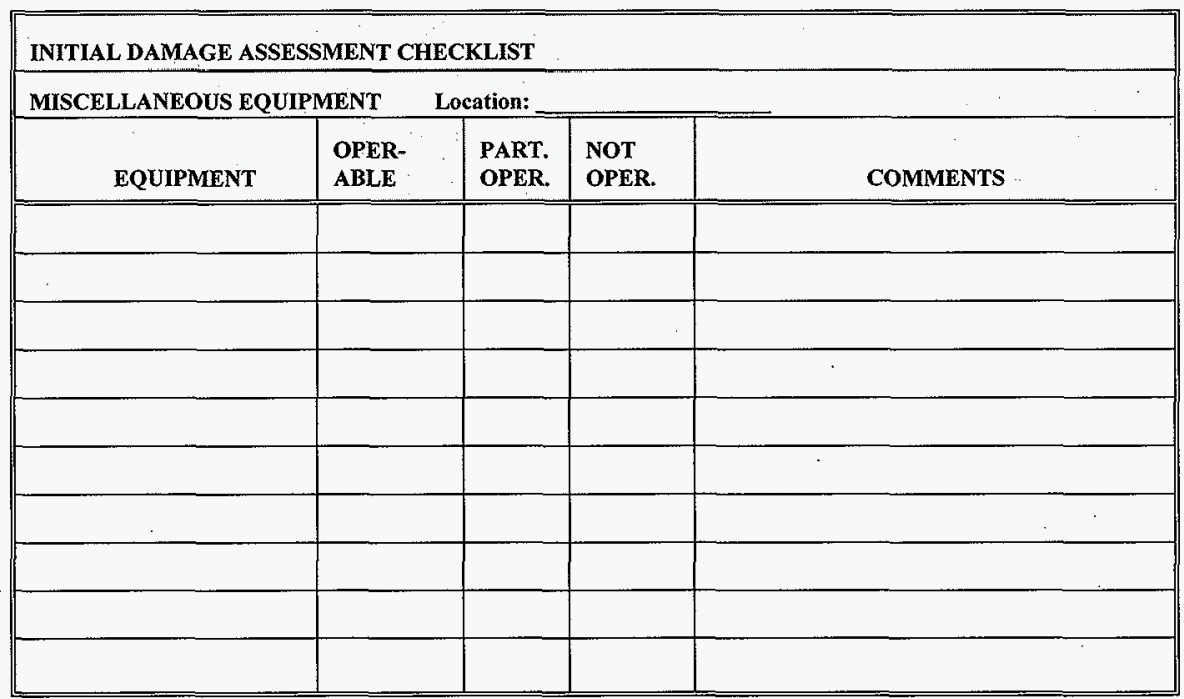




\subsection{APPENDIX D SECOND DISASTER RECOVERY TEAM MEETING}

This section contains a checklist agenda, general checklists to be utilized by Recovery Team Member and hardware information for the second recovery team meeting held after the notification of a disaster is received.

\section{SECOND DISASTER RECOVERY CHECKLIST}

\begin{tabular}{|c|c|c|c|}
\hline \multicolumn{4}{|c|}{ SECOND DISASTER RECOVERY CHECKLIST } \\
\hline ACTION & $\begin{array}{c}\text { ASSIGNED } \\
\text { TO }\end{array}$ & $\begin{array}{l}\text { ESTIMATED } \\
\text { CONCLUSION }\end{array}$ & COMPLETE \\
\hline ENSURE PERSONNEL SAFETY & Team & & \\
\hline Obtain and integrate functional damage assessments. & Team & $\begin{array}{l}\text { This } \\
\text { meeting }\end{array}$ & \\
\hline $\begin{array}{l}\text { Identify and quantify remaining production capability of the } \\
\text { computer center that can be available for production in a few } \\
\text { days. }\end{array}$ & Team & $\begin{array}{l}\text { This } \\
\text { meeting }\end{array}$ & \\
\hline Identify jobs that were interrupted during processing. & Prod Ctrl & $\begin{array}{l}\text { This } \\
\text { meeting }\end{array}$ & \\
\hline $\begin{array}{l}\text { Decide which essential applications can be processed in the data } \\
\text { center. }\end{array}$ & $\begin{array}{l}\text { Prod } \\
\text { ctrl/Tech }\end{array}$ & $\begin{array}{l}\text { This } \\
\text { meeting }\end{array}$ & \\
\hline Identify the cleanup and repair required to support production. & Team & $\begin{array}{l}\text { This } \\
\text { meeting }\end{array}$ & \\
\hline 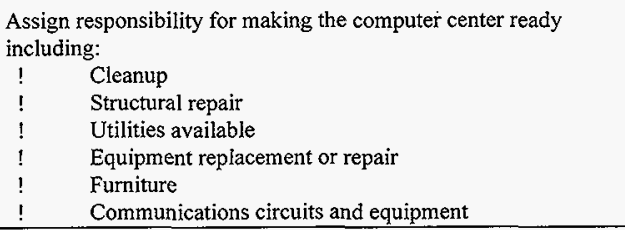 & Team & $\begin{array}{l}\text { This } \\
\text { meeting }\end{array}$ & \\
\hline $\begin{array}{l}\text { Assign responsibility for computer center production preparation } \\
\text { and restart. } \\
!\end{array}$ & Team & $\begin{array}{l}\text { This } \\
\text { meeting }\end{array}$ & \\
\hline Identify additional production capacity requirements by program. & Team & $\begin{array}{l}\text { This } \\
\text { meeting }\end{array}$ & \\
\hline $\begin{array}{l}\text { Assign responsibility to locate and negotiate for additional } \\
\text { capacity required. }\end{array}$ & Team & $\begin{array}{l}\text { This } \\
\text { meeting }\end{array}$ & \\
\hline
\end{tabular}




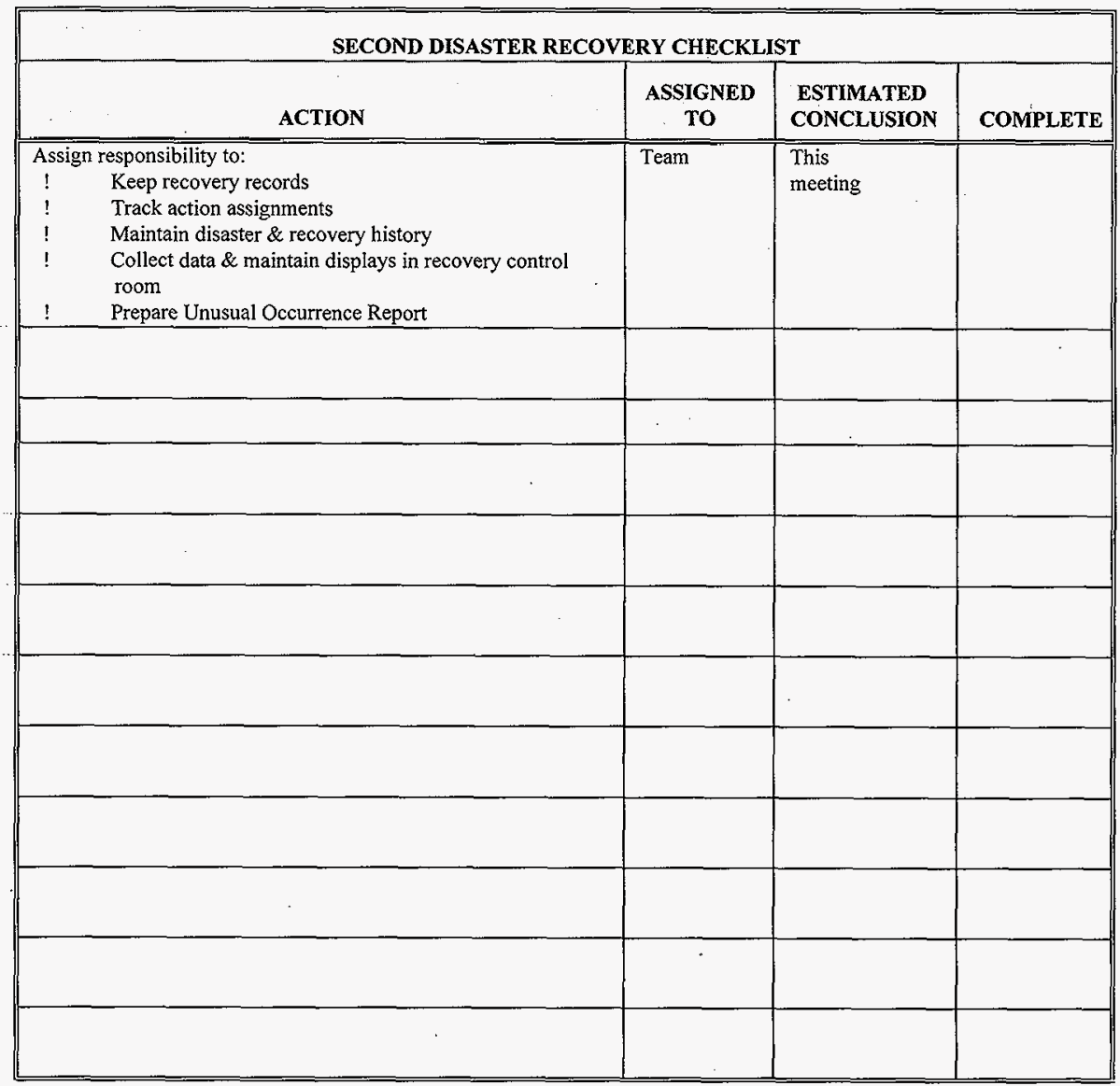

Prod Ctrl-Production Control Team-Disaster Recovery Team

Tech-Technology 
DISASTER RECOVERY GENERAL CHECKLIST

\begin{tabular}{|c|c|c|c|}
\hline \multicolumn{4}{|c|}{ DISASTER RECOVERY GENERAL CHECKLIST } \\
\hline ACTION & $\begin{array}{l}\text { ASSIGNED } \\
\text { TO }\end{array}$ & $\begin{array}{l}\text { ECD } \\
\text { TIME/DATE }\end{array}$ & $\begin{array}{l}\text { COMPLETE } \\
\text { TIME/DATE }\end{array}$ \\
\hline ENSURE PERSONNEL SAFETY. & Manager & & \\
\hline Notify all customers. & Sys Admin & & \\
\hline Establish emergency control room. & Fac & & \\
\hline Assess and record extent of damage. & $\begin{array}{l}\text { Fac/Oprs/Vend/ } \\
\text { Telecom/ } \\
\text { Sys Admin } \\
\end{array}$ & & \\
\hline Determine remaining capability and capacity. & $\begin{array}{l}\text { Fac/Oprs/Vend/ } \\
\text { Telecom/ } \\
\text { Sys Admin }\end{array}$ & & \\
\hline Determine what applications will process on remaining capacity. & $\begin{array}{l}\text { Tech/Sys Admin/ } \\
\text { Prod Ctrl }\end{array}$ & & \\
\hline Establish job recovery priorities. & Prod Ctrl & & \\
\hline $\begin{array}{l}\text { Prepare computer and communications hardware replacement } \\
\text { list. }\end{array}$ & $\begin{array}{l}\text { Tech/Vend/ } \\
\text { Telecom }\end{array}$ & & \\
\hline Ascertain how soon the replacement hardware will be available. & $\begin{array}{l}\text { Procurement/ } \\
\text { Vend }\end{array}$ & & \\
\hline $\begin{array}{l}\text { Ascertain if there is floor space available for replacement } \\
\text { hardware. }\end{array}$ & Fac & & . \\
\hline Ascertain if alternate-processing capability is required. & Team & & \\
\hline Define amount and type of work to be off-loaded. & Tech/Prod Ctrl & & \\
\hline Designate an alternate or off load leader. & Manager & & \\
\hline Assign personnel required to process applications at remote site. & Manager & & \\
\hline $\begin{array}{l}\text { Make appropriate arrangements to move applications to alternate } \\
\text { site. }\end{array}$ & Manager & & \\
\hline Start facility restoration. & Facilities & & \\
\hline Prepare and process purchase orders. & Support Serv & & \\
\hline Contact vendor and supply sources. & Procurement & & \\
\hline Start restoring communications - data. & Telecom & & \\
\hline Start restoring telephone - voice. & Telecom & & \\
\hline
\end{tabular}




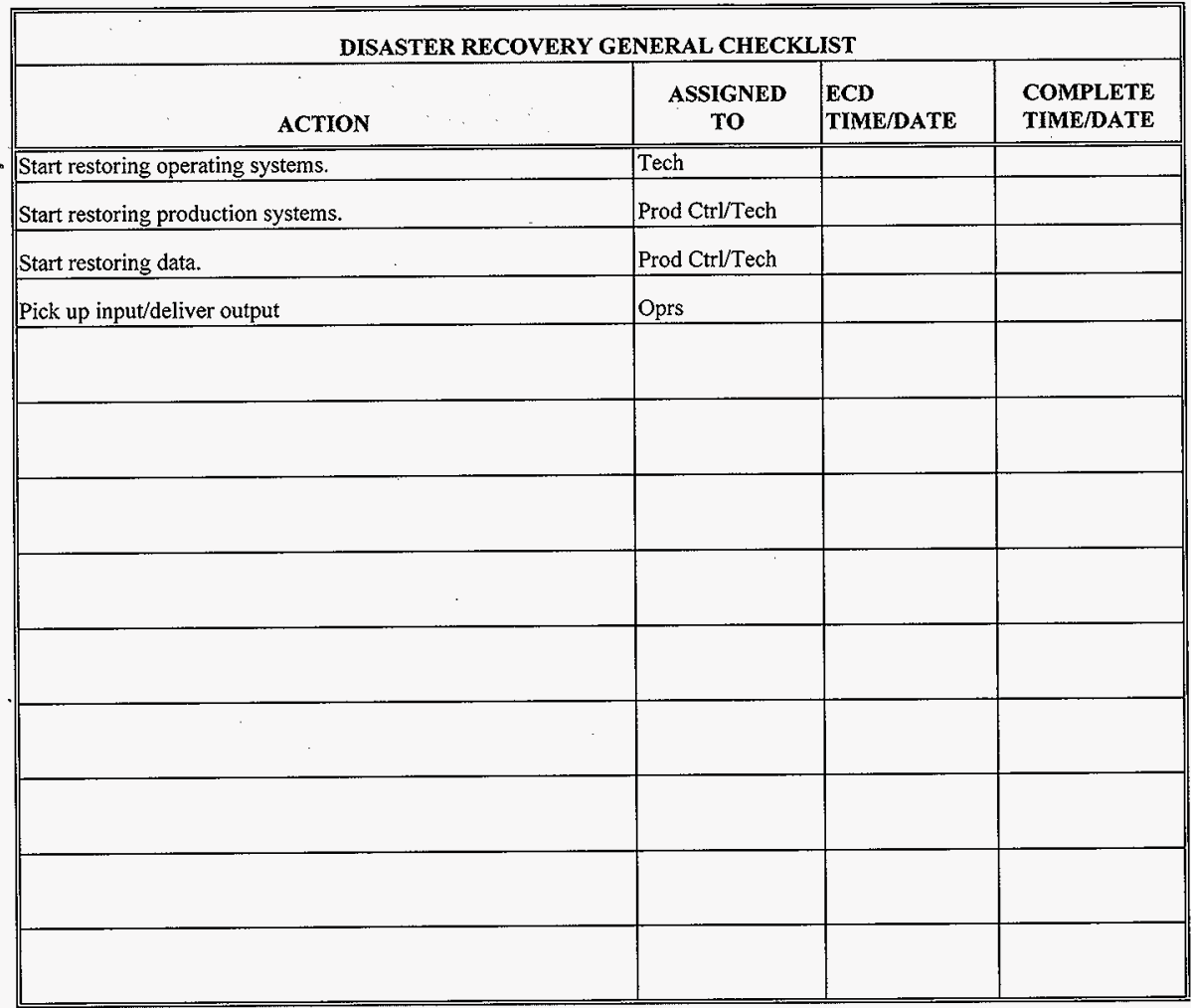

Fac-Facilities

Tech-Technology

Prod Ctrl-Production Control Telecom-Telecommunications

Oprs-Operations

Vend-Vendor

Sys Admin-System Administrator 
DISASTER RECOVERY ALTERNATE PROCESSING CHECKLIST

\begin{tabular}{|c|c|c|c|}
\hline \multicolumn{4}{|l|}{$\begin{array}{l}\text { DISASTER RECOVERY } \\
\text { ALTERNATE PROCESSING CHECKLIST }\end{array}$} \\
\hline ACTION & $\begin{array}{l}\text { ASSIGNED } \\
\text { TO }\end{array}$ & $\begin{array}{l}\text { ECD } \\
\text { TIME/DATE }\end{array}$ & $\begin{array}{l}\text { COMPLETE } \\
\text { TIME/DATE }\end{array}$ \\
\hline \multicolumn{4}{|l|}{ ENSURE PERSONNEL SAFETY } \\
\hline Identify and make arrangements with an alternate site. & $\begin{array}{l}\text { Info \& Sc } \\
\text { Sys/Ops/Prod } \\
\text { Ctrl }\end{array}$ & & \\
\hline Identify systems/applications to be off-loaded. & $\begin{array}{l}\text { Info \& Sci } \\
\text { Sys/Prod } \\
\text { Ctrl/Customers }\end{array}$ & & \\
\hline $\begin{array}{l}\text { Define computer and communications hardware requirements for each } \\
\text { off-load item. }\end{array}$ & $\begin{array}{l}\text { Info \& Sci } \\
\text { Sys/Tech/ } \\
\text { Telcomm }\end{array}$ & & \\
\hline Locate potential off load locations based on hardware requirements. & Oprs/Tech & & \\
\hline Notify off load sites of status and requirements. & Prod Ctrl/Tech & & \\
\hline Retrieve backup systems tapes for sending to alternate location. & Tape Lib & & \\
\hline Generate a new system if required and test at off load site. & Tech & & \\
\hline $\begin{array}{l}\text { Assemble all necessary resources for processing identified work at } \\
\text { alternate site. } \\
\begin{array}{l}\text { Recall JCL, load modules, data libraries, disk files, tape files, } \\
\text { data input, RJE input, key personnel }\end{array}\end{array}$ & $\begin{array}{l}\text { Info \& Sci } \\
\text { Sys/Prod } \\
\text { CtrlOps }\end{array}$ & & \\
\hline $\begin{array}{ll}\text { Arrange } & \text { Transportation } \\
! & \text { Local } \\
! & \text { Off Site }\end{array}$ & Ops/Prod Ctrl & & \\
\hline Staffing & $\begin{array}{l}\text { Info \& Sci } \\
\text { Sys/Tech/Prod } \\
\text { Ctrl/Telecom } \\
\end{array}$ & & \\
\hline Supplies & Oprs & & \\
\hline
\end{tabular}

Info \& Sci Sys-Information And Scientific Systems Tape Lib-Tape Librarian

Prod Ctrl-Production Control

Oprs-Operations

Sys Admin-System Administrator
Tech-Technology

Telecom-Telecommunications

Vend-Vendor 


\section{APPENDIX E COMPUTER OPERATIONS}

The Computer Operations member of the Disaster Recovery Team represents Computer Operations and Tape Library. This appendix provides a general checklist that provides directions and serves as reminders of actions to take and situations to review. The Contact List maintained by each department is used to notify key personnel of the disaster and direct them to the proper location to assist in the recovery action.

COMPUTER OPERATIONS GENERAL CHECKLIST

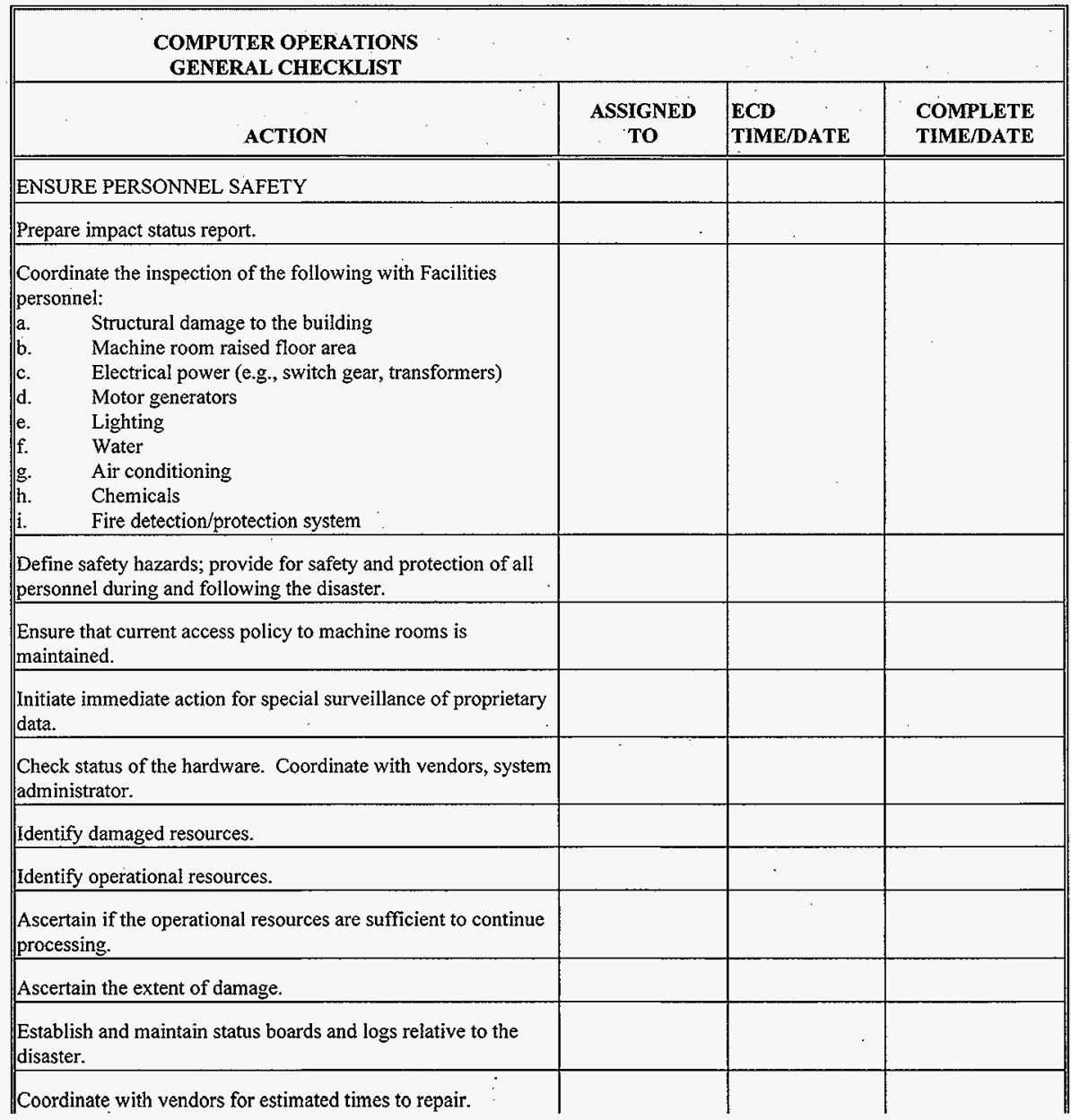




\section{COMPUTER OPERATIONS GENERAL CHECKLIST}

\begin{tabular}{|c|c|c|c|}
\hline ACTION & $\begin{array}{l}\text { ASSIGNED } \\
\text { TO }\end{array}$ & $\begin{array}{l}\text { ECD } \\
\text { TIME/DATE }\end{array}$ & $\begin{array}{l}\text { COMPLETE } \\
\text { TIME/DATE }\end{array}$ \\
\hline \multicolumn{4}{|l|}{ Identify the components that require replacement. } \\
\hline $\begin{array}{l}\text { Assess and document the disaster impact. Furnish the report to } \\
\text { appropriate Disaster Recovery Team members. }\end{array}$ & & & . \\
\hline $\begin{array}{l}\text { Forward all inquires from those involved in the disaster } \\
\text { recovery process to the Disaster Team Manager. }\end{array}$ & & . & \\
\hline $\begin{array}{l}\text { Pull recovery records, as required, } \\
\text { from Operations: }\end{array}$ & & & \\
\hline $\begin{array}{ll}\text { a. } & \text { Configuration Logical Layouts } \\
\text { b. } & \text { Physical Layout of Facilities (floor plans) } \\
\text { c. } & \text { Work Center Procedures } \\
\end{array}$ & & & \\
\hline $\begin{array}{l}\text { Coordinate with System Administrator (SA) to define status of } \\
\text { software: } \\
\text { a. Have the systems packs been destroyed or damaged? } \\
\text { b. } \quad \text { Coordinate with SA to rebuild system. }\end{array}$ & & & \\
\hline $\begin{array}{l}\text { If appropriate; direct Tape Librarians to pull operating system } \\
\text { and application recovery tapes as required from the Record } \\
\text { Center and the } 2261 \text { Building. }\end{array}$ & & & \\
\hline $\begin{array}{l}\text { Coordinate with Production Control to evaluate job-processing } \\
\text { status when the service was interrupted and to prioritize work } \\
\text { on remaining resources. }\end{array}$ & & & \\
\hline $\begin{array}{l}\text { Arrange special transportation for data and output products } \\
\text { (trucks, taxi, and special delivery services). }\end{array}$ & & & \\
\hline $\begin{array}{l}\text { Establish or expand controls to protect all customer data within } \\
\text { the organization's jurisdiction. }\end{array}$ & & & \\
\hline $\begin{array}{l}\text { Coordinate with Production Control to determine if off load or } \\
\text { alternate processing is required. }\end{array}$ & & & \\
\hline $\begin{array}{l}\text { Acquire the tools required for alternate operations (work center } \\
\text { logs, checklists, procedures). }\end{array}$ & & & \\
\hline 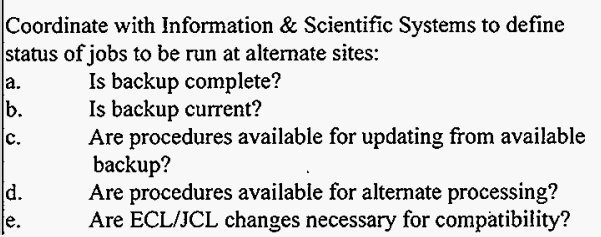 & & & \\
\hline
\end{tabular}




\begin{tabular}{|c|c|c|c|}
\hline \multicolumn{4}{|l|}{$\begin{array}{l}\text { COMPUTER OPERATIONS } \\
\text { GENERAL CHECKLIST }\end{array}$} \\
\hline ACTION & $\begin{array}{l}\text { ASSIGNED } \\
\text { TO }\end{array}$ & $\begin{array}{l}\text { ECD } \\
\text { TIME/DATE }\end{array}$ & $\begin{array}{l}\text { COMPLETE } \\
\text { TIME/DATE }\end{array}$ \\
\hline Are special report forms needed? & & & \\
\hline $\begin{array}{l}\text { Coordinate with the backup sites for arrangement for machine } \\
\text { time. }\end{array}$ & & & \\
\hline $\begin{array}{l}\text { Prepare staffing plan for all work centers to support disaster } \\
\text { recovery-provide for 24-hour coverage. }\end{array}$ & & & \\
\hline Prepare staffing plan to support any alternate processing. & & & \\
\hline $\begin{array}{l}\text { Make transportation arrangements for people, data, and } \\
\text { supplies for alternate processing. }\end{array}$ & & & \\
\hline Alert vendors for need of special support and services. & & & \\
\hline $\begin{array}{l}\text { Coordinate with CIO office for replacement of equipment, } \\
\text { supplies and facility to provide recovery. }\end{array}$ & & & \\
\hline $\begin{array}{l}\text { Coordinate with other Disaster Recovery Team members for } \\
\text { notification and communication with customers as to impact of } \\
\text { disaster on their application: } \\
\text { a. } \\
\begin{array}{l}\text { Provide estimate of time to recover to normal } \\
\text { processing. } \\
\text { b. Set up means to provide customers status of recovery } \\
\text { activity. }\end{array}\end{array}$ & & & \\
\hline $\begin{array}{l}\text { Perform inventory of the work centers; include tools and } \\
\text { special equipment: } \\
\text { tapes, disks, bursters (forms), paper stock, decollators, special } \\
\text { forms, packaging supplies, ribbons, procedures. }\end{array}$ & & & \\
\hline $\begin{array}{l}\text { Coordinate with Telecommunications and Technical Support } \\
\text { for checkout and/or restoration of the communications network }\end{array}$ & & & \\
\hline $\begin{array}{l}\text { Coordinate with Production Control to develop a recovery } \\
\text { schedule based on available resources and priority of workload. }\end{array}$ & & & \\
\hline $\begin{array}{l}\text { Coordinate with Production Control for materials required for } \\
\text { job execution -- JCL, load modules, data libraries, disk files, } \\
\text { tape files, procedures. }\end{array}$ & & & \\
\hline Coordinate special transportation arrangements. & & & \\
\hline $\begin{array}{l}\text { Coordinate with Property Administrator for current listing and } \\
\text { location of equipment within the Hanford area. }\end{array}$ & & & \\
\hline Coordinate with Prod. Control to develop a recovery schedule. & & & \\
\hline & & & \\
\hline
\end{tabular}




\section{6}

APPENDIX F PRODUCTION CONTROL

The Production Control member of the Disaster Recovery Team represents Production Control Staging, Scheduling and System Recovery. This appendix provides a series of checklists and special instructions. The checklists and special instructions provide directions and serve as reminders of actions to take and situations to review. The Contact List maintained by each department is used to notify key personnel of the disaster and direct them to the proper location to assist in the recovery action.

\section{PRODUCTION CONTROL GENERAL CHECKLIST}

\begin{tabular}{|c|c|c|c|}
\hline \multicolumn{4}{|l|}{$\begin{array}{l}\text { PRODUCTION CONTROL } \\
\text { GENERAL CHECKLIST }\end{array}$} \\
\hline ACTION & $\begin{array}{l}\text { ASSIGNED } \\
\text { TO }\end{array}$ & $\begin{array}{l}\text { ECD } \\
\text { TIME/DATE }\end{array}$ & $\begin{array}{l}\text { COMPLETE } \\
\text { TIME/DATE }\end{array}$ \\
\hline \multicolumn{4}{|l|}{ ENSURE PERSONNEL SAFETY } \\
\hline $\begin{array}{l}\text { Establish a base of operations for: } \\
\begin{array}{ll}\text { a. } & \text { Production Control \& Scheduling } \\
\text { b. } & \text { System Recovery } \\
\text { c. } & \text { Applications Analysts } \\
\end{array}\end{array}$ & & & \\
\hline \multicolumn{4}{|l|}{$\begin{array}{l}\text { Coordinate with communications for required telephone } \\
\text { communications. }\end{array}$} \\
\hline \multicolumn{4}{|l|}{ Notify a sub-team of Production Control to be on standby. } \\
\hline 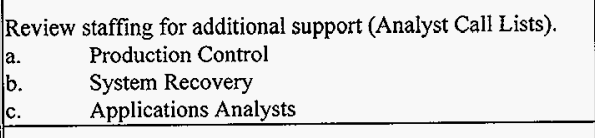 & & & \\
\hline \multicolumn{4}{|l|}{$\begin{array}{l}\text { Review production work in progress and work schedule. } \\
\text { Distribute information to Computer Operations Manager, } \\
\text { Recovery, Scheduling, Information \& Scientific Systems. }\end{array}$} \\
\hline \multicolumn{4}{|l|}{$\begin{array}{l}\text { Develop a preliminary assessment of status of in-house jobs } \\
\text { (processing required, resource estimates, etc.) to be furnished } \\
\text { to the Disaster Recovery Team members. }\end{array}$} \\
\hline \multicolumn{4}{|l|}{$\begin{array}{l}\text { Identify the critical applications by day. Distribute } \\
\text { information to Computer Operations Manager, Recovery, } \\
\text { Scheduling, Information \& Scientific Systems. }\end{array}$} \\
\hline \multicolumn{4}{|l|}{$\begin{array}{l}\text { Make an assessment of the applications that will have to be } \\
\text { run. Review job-to-job feeds and data set retention. }\end{array}$} \\
\hline $\begin{array}{l}\text { Determine from other Disaster Recovery. Team members if } \\
\text { the applications will be run on site after a computer center fix } \\
\text { or if off load will be required because of lengthy down time. }\end{array}$ & & & \\
\hline $\begin{array}{l}\text { Call program managers/supervisors for analyst support on } \\
\text { specific applications. }\end{array}$ & & & \\
\hline
\end{tabular}




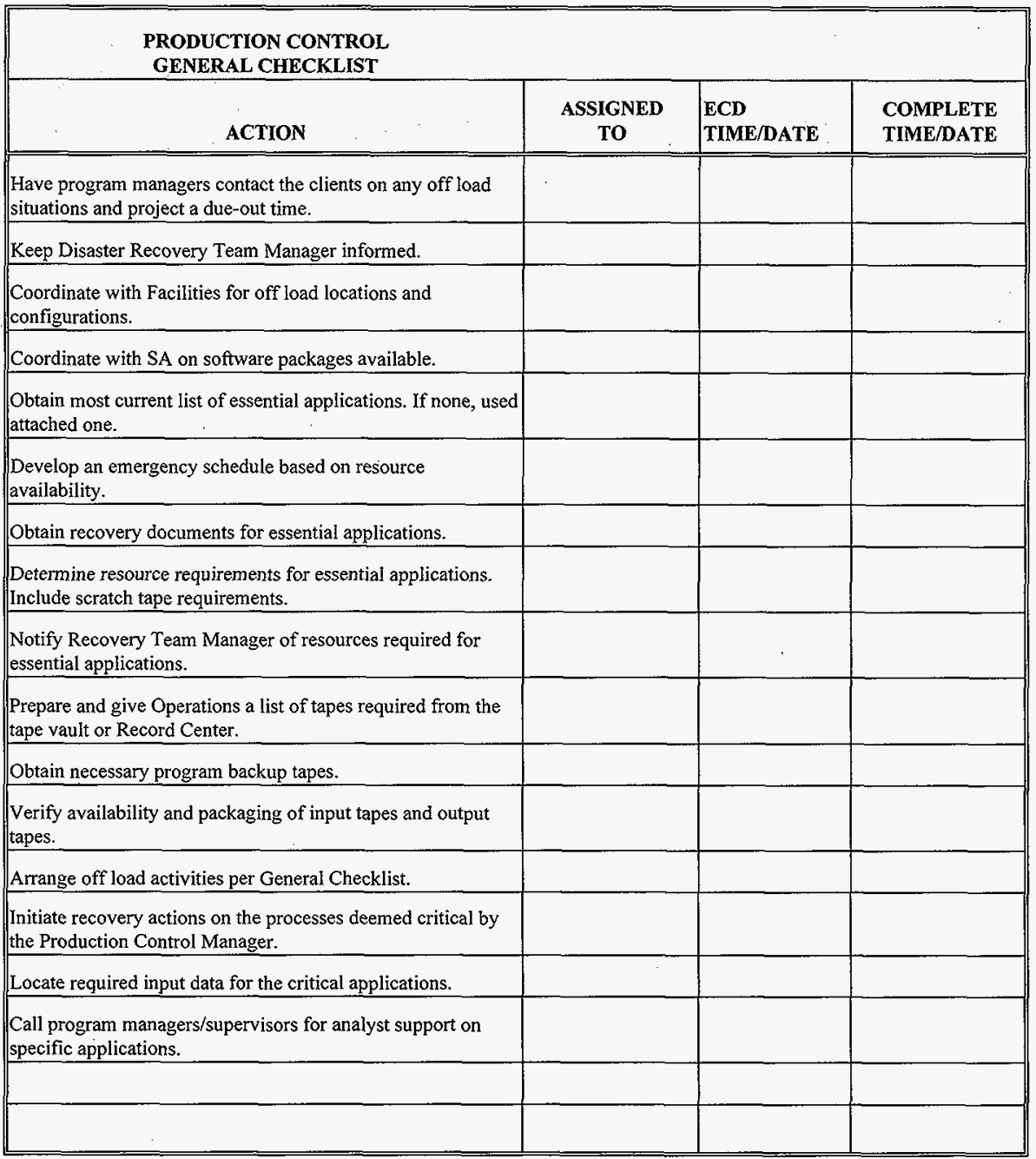




\section{RECOVERY GENERAL CHECKLIST}

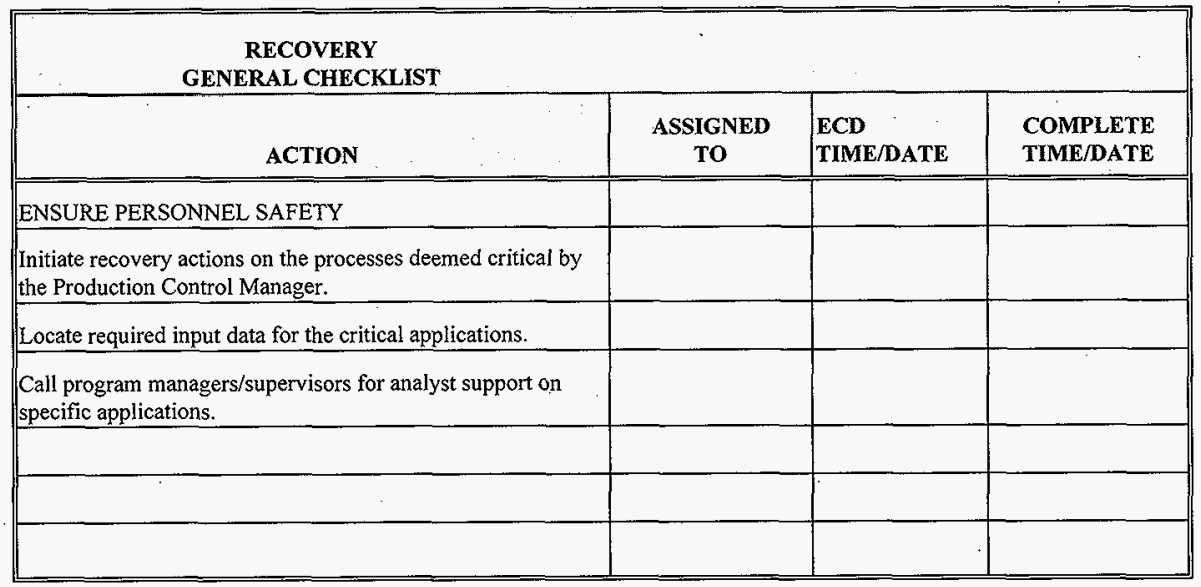




\title{
6.7 APPENDIX G LIST OF ESSENTIAL APPLICATIONS
}

Application Managers through FY98. Application managers for post implementation TBD.

\section{LIST OF ESSENTIAL APPLICATIONS $\quad$ 03/04/98}

\author{
APPLICATION \\ NAME \\ Production Oracle \\ Indus PassPort Database \\ PeopleSoft Financial Database \\ Indus PassPort Client \\ PeopleSoft Financials Client \\ HRIS PeopleSoft Database \\ HRIS PeopleSoft Client \\ P3 Primavera
}

APLICATION

MANAGER

\section{PLATFORM}

Computer Systems Manager

HP UNIX

FDH Supply Implementation Lead

HP UNIX

FDH Finance Implementation Lead

HP UNIX

FDH Supply Implementation Lead

HP UNIX

FDH Finance Implementation Lead

NT SERVER

FDH HR/Payroll Implementation Lead

NT SERVER

FDH HR/Payroll Implementation Lead

NT SERVER

FDH Project Planning Lead

NT SERVER 


\subsection{APPENDIX H TECHNOLOGY CHECKLIST}

The Technology member of the Disaster Recovery Team is responsible for the following during the recovery process:

- Operating System Technology

- Database Administration/On-line Technology

- Systems Integration

The Contact List is used to notify key personnel of the disaster and direct them to the proper location to assist in the recovery action.

TECHNOLOGY GENERAL CHECKLIST

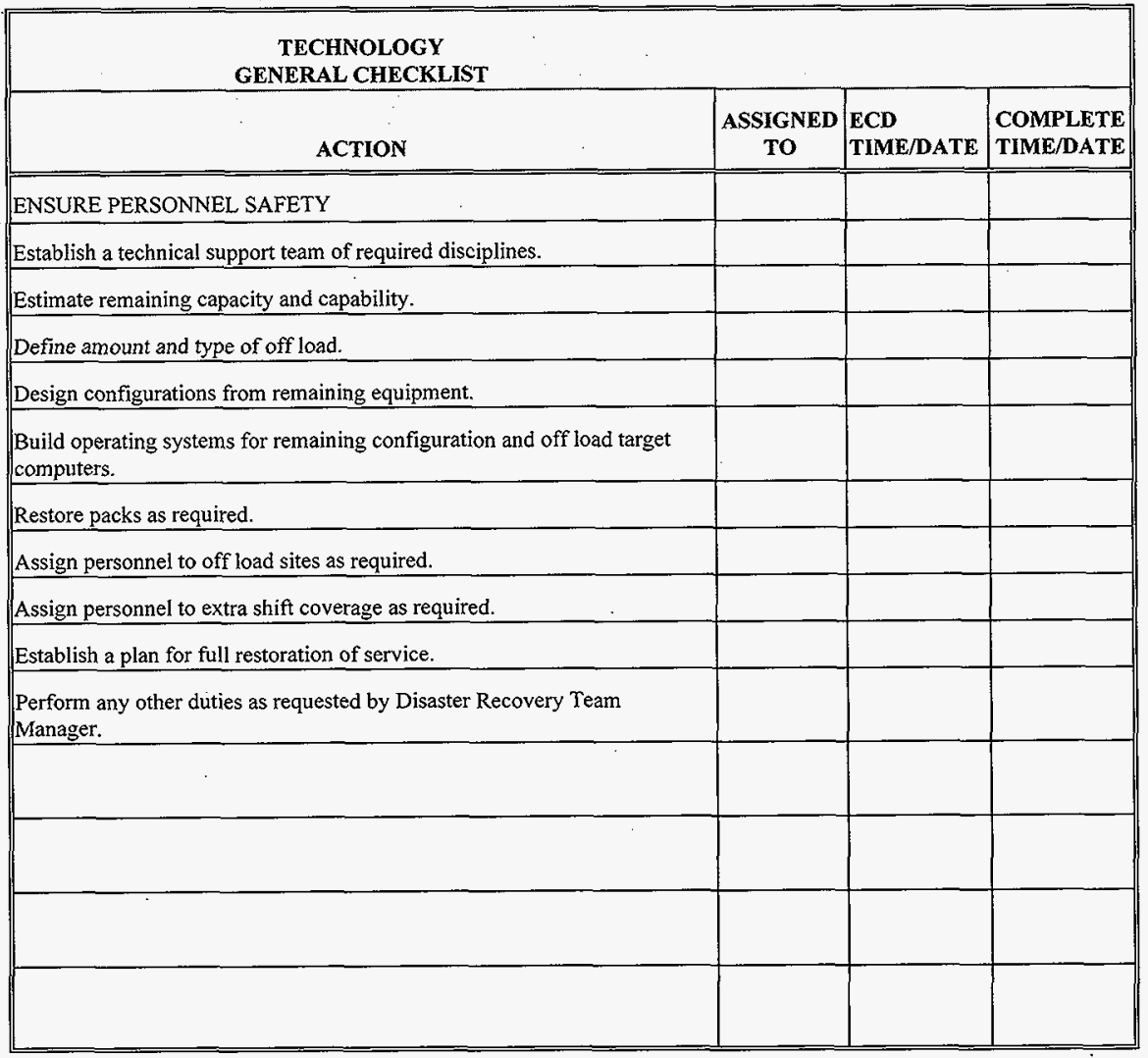


6.9 APPENDIX I MINIMUM CONFIGURATION FOR PROCESSING BMS APPLICATIONS

MINIMUM CONFIGURATION FOR PROCESSING ESSENTIAL APPLICATIONS IN A DISASTER

ENVIRONMENT

APPLICATION: HANDY H2K UNIX

COMPONENT

HARDWARE:

HP9000 K CLASS SERVER

12GB DISK SPACE INTERNAL

2 GB RAM

EMC SYMMETRIX 3430:

108 GB USEABLE, 1GB CASHE

SOFTWARE:

HP-UX 10.20

ORACLE 7.3.2 AND 7.3.3

MICRO FOCUS COBOL 4.0 AND 4.1

PEOPLESOFT 7.0

PASSPORT 6.1

ANSI C

APPLICATION: P3 PRIMAVERA

COMPONENT

HARDWARE

HP LH2 SERVER

256 MEG MEMORY

NET RAID CONTROLLER

45 GIGABYTE DRIVE SPACE

SOFTWARE

MICROSOFT NT 4.0

P3 PREMAVERA

APPLICATION: HRIS / PAYROLL

COMPONENT

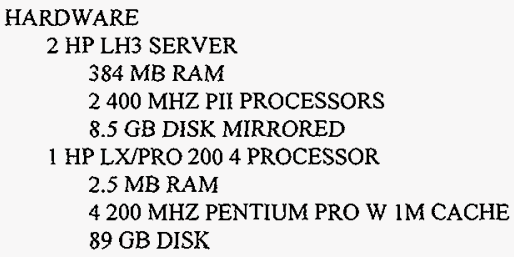


I COMPAQ PROLIANT

P166 W 512 MB CACHE

50 GB DISK

64 MB RAM

SOFTWARE

MICROSOFT NT 4.0

MICROSOFT SQL SERVER

PEOPLESOFT 7.0

\section{APPLICATION: APPLICATION SERVERS}

\section{COMPONENT}

HARDWARE

HP PENTIUM PRO 200 SERVER

128 MEG MEMORY

NET RAID CONTRÓLLER

20 GIGABYTE DRIVE SPACE

SOFTWARE

MICROSOFT NT 4.0

PEOPLESOFT CLIENT SOFTWARE

PASSPORT CLIENT SOFTWARE

\section{APPLICATION: CA UNICENTER}

\section{COMPONENT}

HARDWARE

HP PENTIUM PRO 200 SERVER

128 MEG MEMORY

NET RAID CONTROLLER

16 GIGABYTE DRIVE SPACE

SOFTWARE

MICROSOFT NT 4.0

MICROSOFT SQL SERVER

CA UNICENTER 


\subsection{APPENDIX $J$ TELECOMMUNICATIONS FACILITIES RESTORATION PRIORITIES}

The Telecommunications member of the Disaster Recovery Team assesses the extent of damage to the telephone and network facilities. The following network restoration priorities are observed.

1. Dial-up Communications are restored by the telephone vendor and/or Plant Telephone as soon as physically possible.

2. The Remote Access System (RAS) is restored as soon as possible after the Telecommunications Recovery Team is in place.

3. The Microwave System is restored as soon as possible after the Telecommunications Recovery Team is in place.

4. The Hanford Wide Area Network (WAN) consisting primarily of fiber optic, Ethernet and broadband data communications systems, with associated electronics are restored after the Recovery Team has established dial-up service and the Microwave System is operational.

5. The managed computer facility switching equipment, multiplexers, dedicated circuits, modems and front-end processors are restored as soon as possible to support dial-up access.

The On-Call $\mathrm{List}$ is used to notify key personnel of the disaster and direct them to the proper location to assist in the recovery action. 


\section{TELECOMMUNICATIONS GENERAL CHECKLIST}

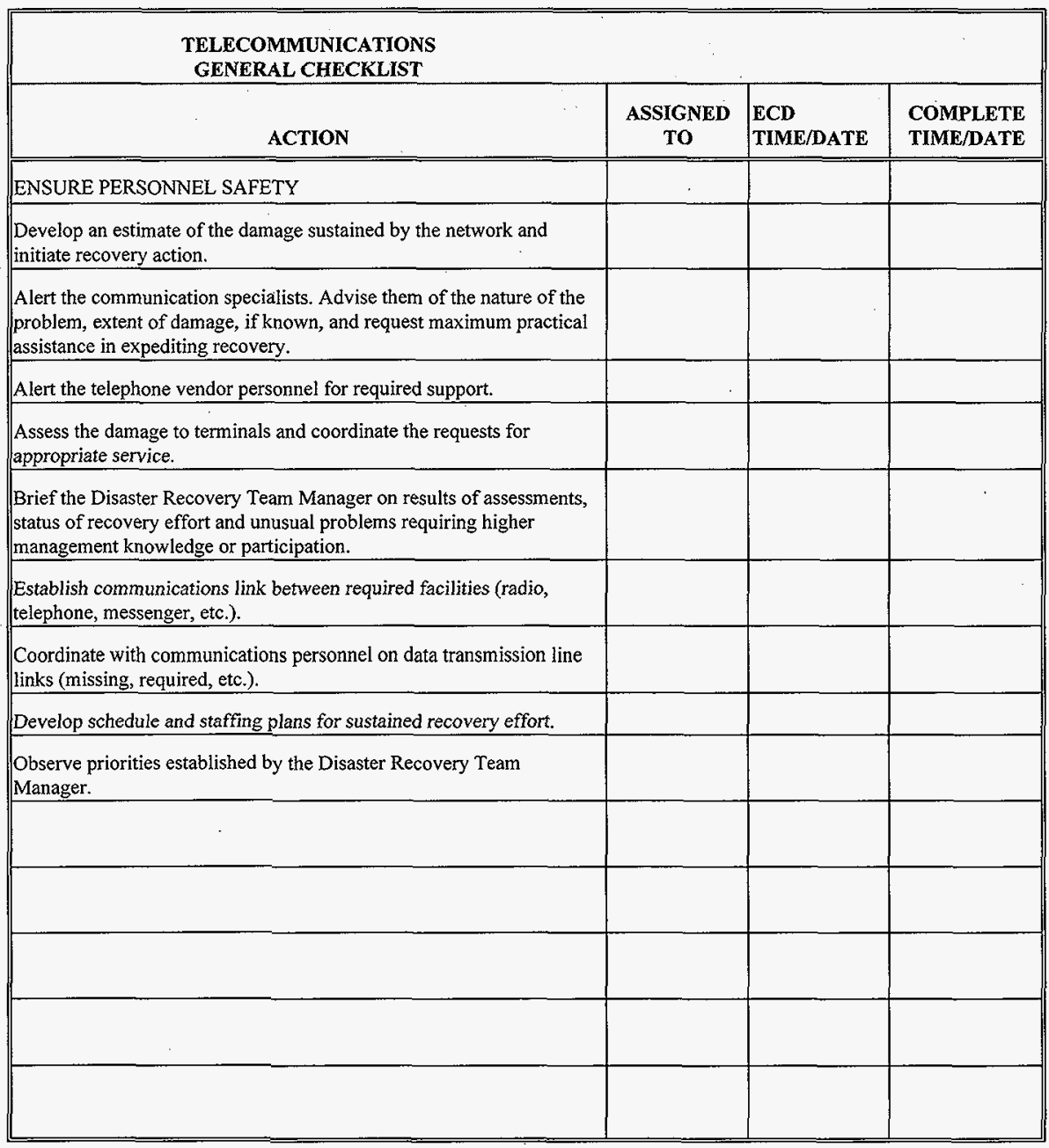




\subsection{APPENDIX K FACILITIES / SECURITY}

The Facilities and Security members of the Disaster Recovery Team participate in the initial damage assessment, and initiate and coordinate the necessary emergency action to restore the damaged facility to a usable condition. Temporary facilities, including a control room for recovery activities, are identified, if the current computer facility is not usable. The Facility team member identifies space as needed in addition to the alternate emergency control rooms. The Security team member ensures that proper security measures have been identified and are in place.

This appendix contains checklists and instructions for emergency and on-going action. The Contact List is used to notify key personnel of the disaster and direct them to the proper location to assist in the recovery action.

\section{FACILITIES/SECURITYGENERAL CHECKLIST}

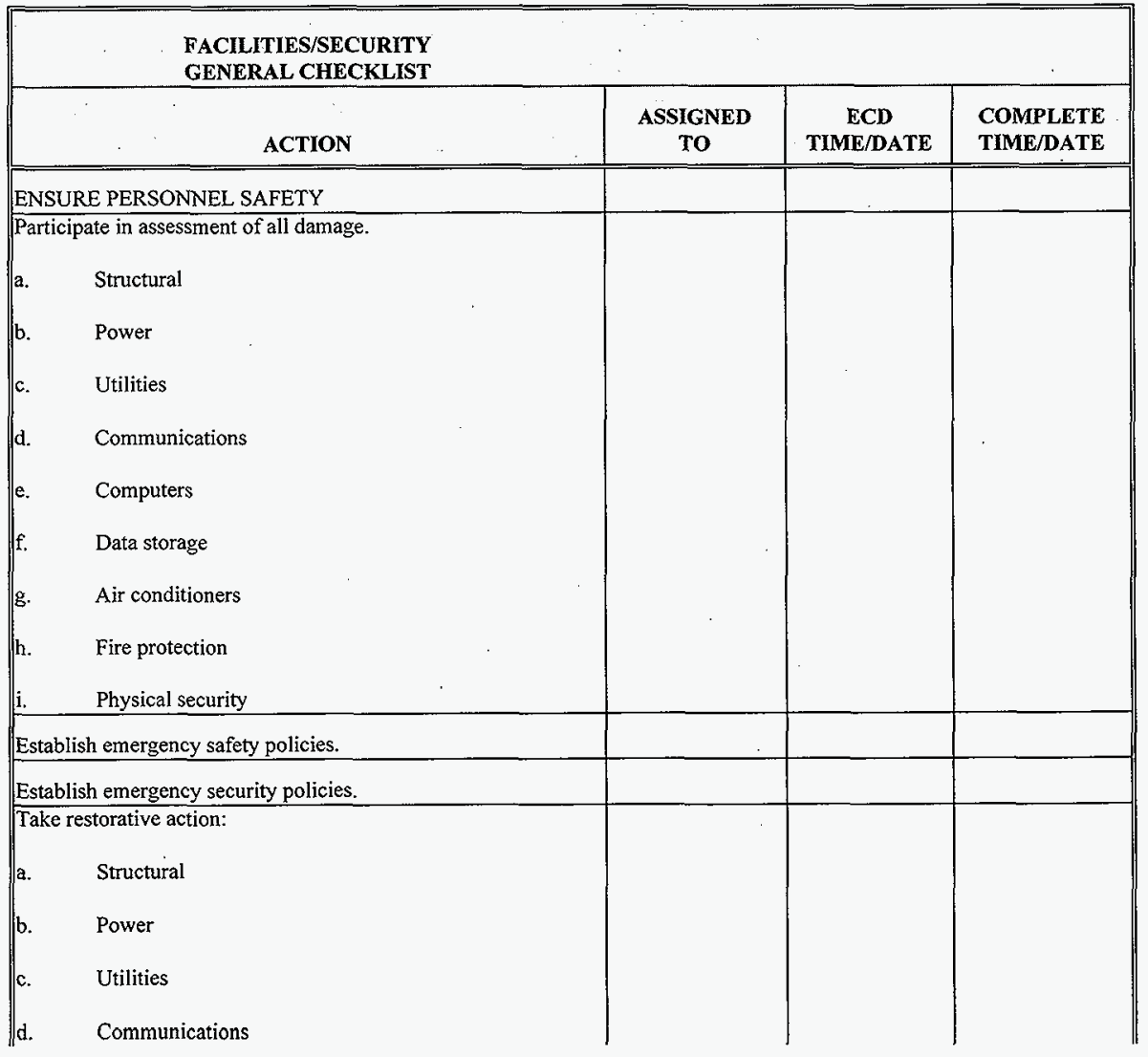




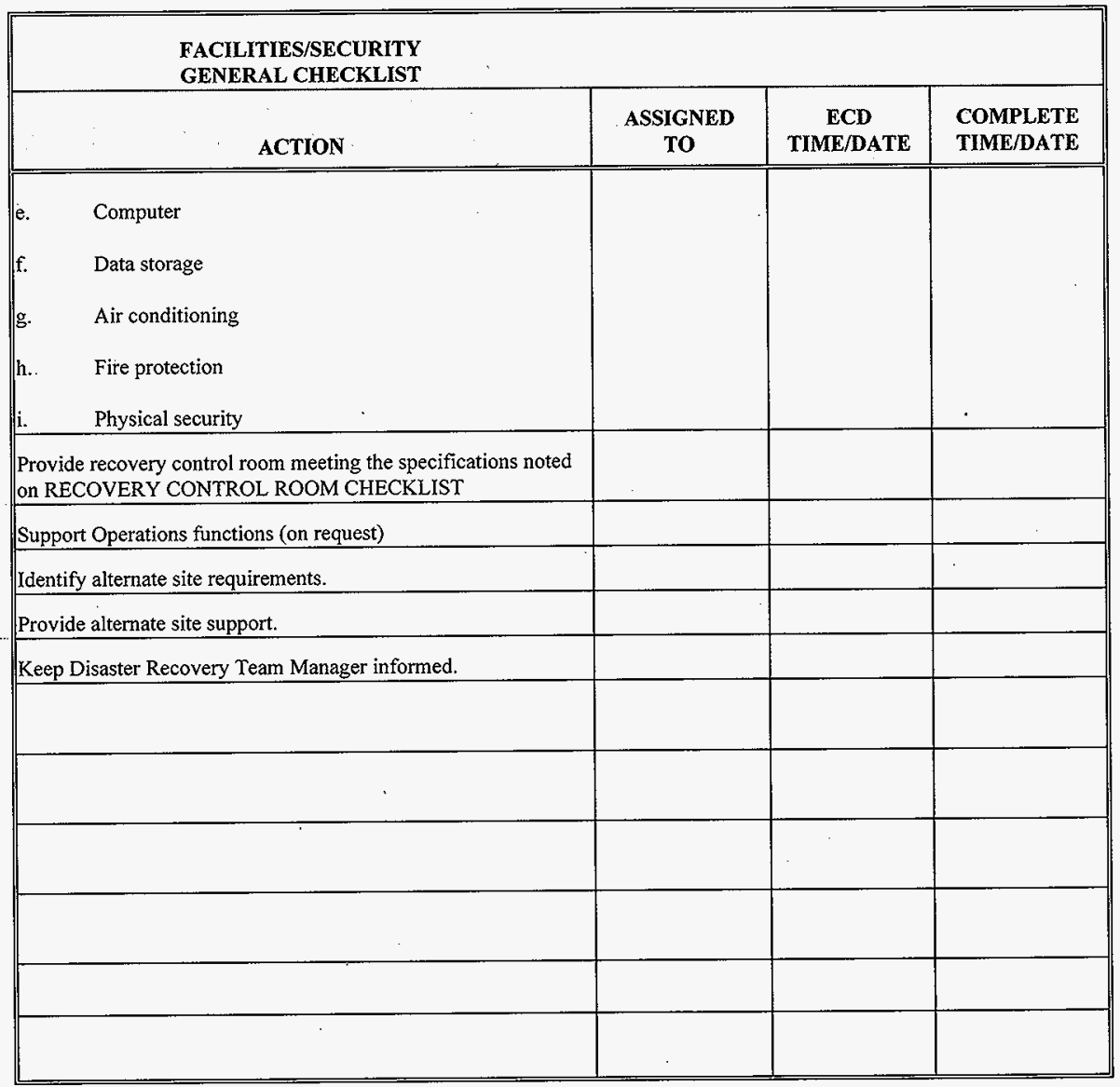




\section{FACILITIES/SECURITYRECOVERY CONTROL ROOM CHECKLIST}

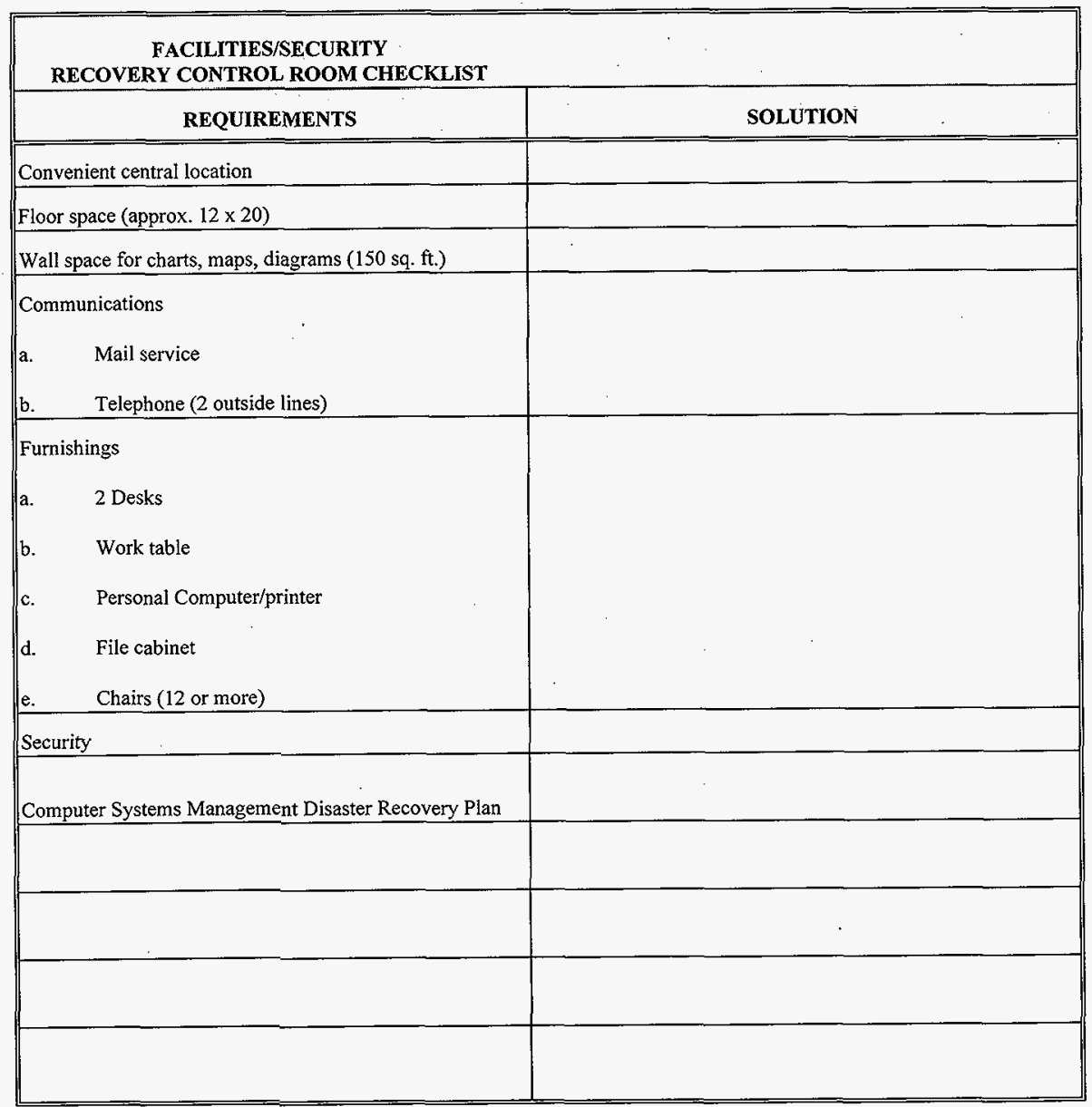




\subsection{APPENDIX L FINANCE}

The Finance Administration member of the Disaster Recovery Team assists the Disaster Recovery Team Manager with the preparation of a financial impact status report defining in detail the cost of the disaster and what acquisitions are needed to recover.

The Checklist serves as a guide and worksheet for recovery activities. The Contact List is used to notify key personnel of the disaster and direct them to the proper location to assist in the recovery action.

\section{FINANCE GENERAL CHECKLIST}

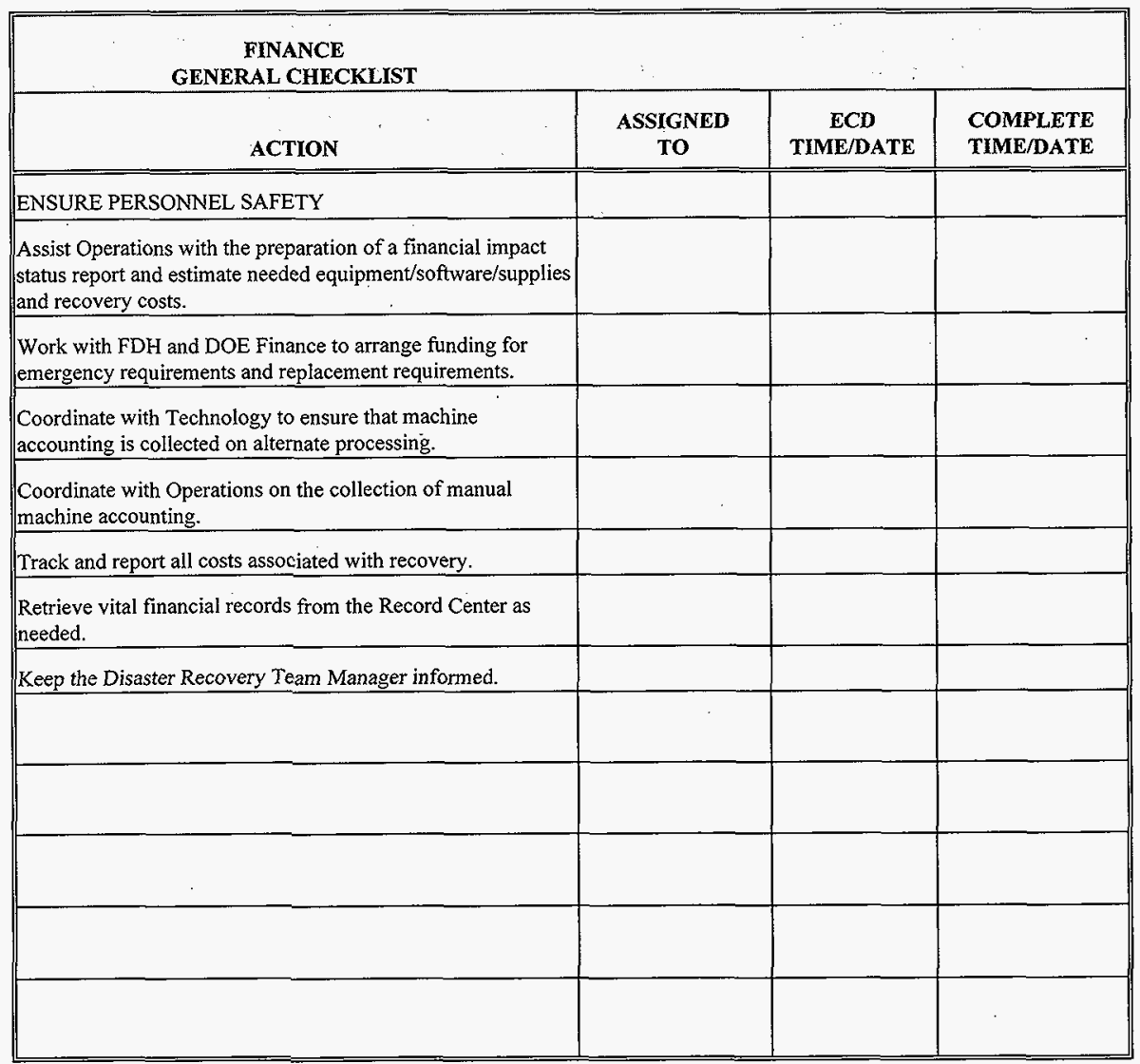




\subsection{APPENDIX M COMPUTER TECHNICAL SUPPORT}

The Computer Technical Support Members of the Disaster Recovery team establishes communications with the HLAN and Mainframe Computer users to assist them with recovery of their computing capabilities. The Computer Technical Support Members will answer inquiries from customers, provide them with status information and report user damage assessment and impacts to the Disaster Recovery Team Manager.

\section{COMPUTER TECHNICAL SUPPORT GENERAL CHECKLIST}

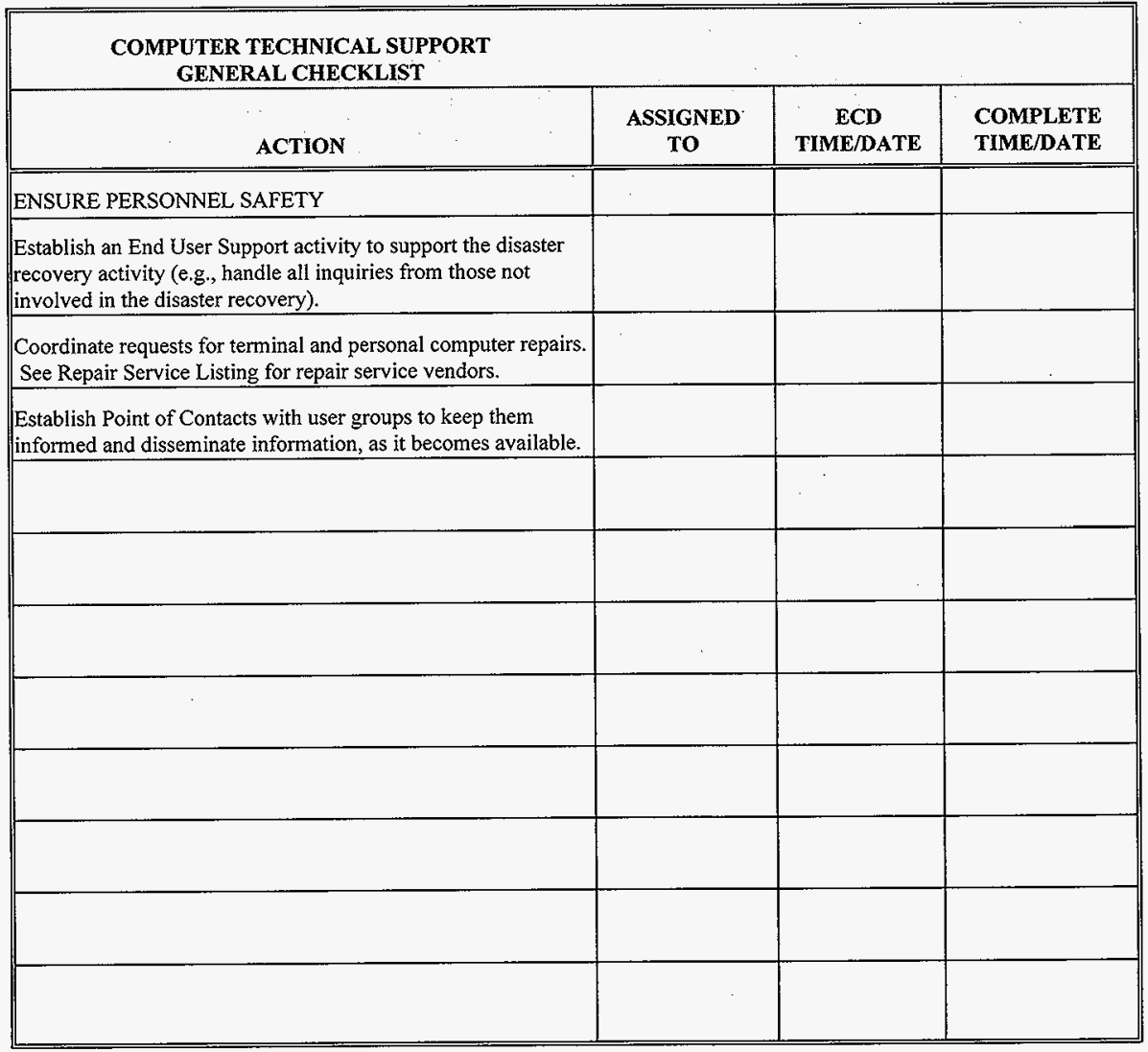

